\title{
PENYAJIAN INFORMASI SPASIAL PERTANAHAN BERBASIS BENCANA TANAH LONGSOR DI GEDANGSARI, GUNUNGKIDUL \\ ${ }^{*}$ Aprin Sulistyani, ${ }^{* *}$ Arief Syaifullah, ${ }^{* * *}$ Kusmiarto
}

\begin{abstract}
Indonesia is in the region with high potential threat of natural disasters. Landslides is the largest and most deadly threat in Indonesia (Gema BNPB 2015). Therefore, disaster risk reduction is needed to minimize the impact of disaster, by encouraging collection, management and access to the risk information using location-based database. To support these efforts, this research sought to describe the distribution of the level of threat, vulnerability, capacity and risk of landslides in the district of Gedangsari through decisive element of risk weighting, which are threats, vulnerabilities and capacities for 67 hamlets in study area. The result were presented as Threat Map, Vulnerability Map, Capacity Map and Landslide Risk Map. Furthermore, these maps were overlayed with Land Registry Map and Technique Base-Map. The results were analyzed using spatial and Quantitative descriptive methods to provide land information-based landslides in Kecamatan Gedangsari. This information is useful to support the work of National Land Agency in providing safe land relocation near to the disaster site and to maintain Cadastral Control Points.
\end{abstract}

Keywords: landslide, land relocation, contol points

Intisari: Wilayah Indonesia berada pada potensi tinggi ancaman bencana alam. Bencana tanah longsor merupakan ancaman terbesar dan paling mematikan di Indonesia (Gema BNPB 2015). Oleh karena itu perlu upaya pengurangan risiko bencana untuk meminimalisir dampak yang ditimbulkan dengan mendorong pengumpulan, manajemen dan akses informasi risiko menggunakan dasar data berbasis lokasi. Dalam rangka mendukung upaya tersebut, penelitian ini mencoba menggambarkan sebaran tingkat ancaman, kerentanan, kapasitas dan risiko bencana tanah longsor di Kecamatan Gedangsari melalui pembobotan unsur penentu risiko yaitu ancaman, kerentanan dan kapasitas pada 67 dusun. Hasilnya, disajikan dalam bentuk Peta Ancaman, Peta Kerentanan, Peta Kapasitas dan Peta Risiko Bencana Tanah Longsor. Selanjutnya, peta-peta tersebut dipadukan dengan Peta Pendaftaran Tanah dan Peta Dasar Teknik. Hasil overlay kemudian dianalisis secara spasial dan deskriptif kuantitatif untuk menyajikan informasi pertanahan berbasis bencana tanah longsor di Kecamatan Gedangsari. Informasi tersebut bermanfaat dalam rangka melaksanakan fungsi Badan Pertanahan Nasional seperti kegiatan penyediaan tanah relokasi yang aman dan dekat dengan lokasi bencana dan pemeliharaan TDT.

Kata kunci: tanah longsor, relokasi tanah, TDT

\section{A. Pendahuluan}

Wilayah Indonesia merupakan gugusan kepulauan terbesar di dunia, berada pada pertemuan tiga lempeng tektonik aktif dunia dan ring offire dan jalur subduksi yang menempatkan Indonesia pada potensi tinggi ancaman bencana alam seperti letusan gunung, gempa bumi dan tsu-

*Aprin Sulistyani, Staff Kantor Pertanahan Kabupaten Ogan Ilir, sulisstya@yahoo.com,**Arief Syaifullah, Dosen STPN, ariefsyaif69@gmail.com, ***Kusmiarto, Dosen STPN, kusmiarto@stpn.ac.id. nami. Bencana lainnya yang diakibatkan oleh ulah manusia dan konservasi yang kurang baik yaitu longsor. Bencana tanah longsor merupakan ancaman terbesar dan paling mematikan di Indonesia sesuai dengan data Gema BNPB (2015) dimana $17,2 \%$ penduduk nasional terpapar langsung oleh bahaya longsor sedang-tinggi. Oleh karena itu perlu upaya pengurangan risiko bencana untuk meminimalisir dampakyang ditimbulkan. Dengan mendorong pengumpulan, manajemen dan akses informasi risiko menggunakan dasar data berbasis 
lokasi dengan mengoptimalkan ilmu pengetahuan dan teknologi, kemudian memanfaatkan informasi risiko tersebut untuk pengurangan risiko bencana. Kementerian ATR/BPN yang melaksanakan tugas pemerintah di bidang pertanahan harus menjadi instansi pendukung dengan menyediakan informasi pertanahan berbasis bencana. Hal tersebut dapat dilakukan oleh kantor pertanahan dengan memadukan peta tematik bencana tanah longsor dengan peta tematik pertanahan.

Penelitian ini mencoba menyediakan informasi pertanahan berbasis bencana tanah longsor di Kecamatan Gedangsari. Berdasarkan data BPBD Kabupaten Gunungkidul, Kecamatan Gedangsari yang terdiri dari tujuh desa seluruhnya rawan bencana tanah longsor. Bencana tanah longsor terjadi setiap tahun dan menimbulkan kerugian harta benda serta korban jiwa. Kejadian bencana tanah longsor lima tahun terakhir sebagai berikut:

Tabel 1. Kejadian Bencana Tanah Longsor di Kecamatan Gedangsari

\begin{tabular}{|c|c|c|l||}
\hline No. & Tahun & $\begin{array}{c}\text { Jumlah Kejadian } \\
\text { Longsor }\end{array}$ & \multicolumn{1}{|c|}{$\begin{array}{c}\text { Lokasi } \\
\text { (Desa) }\end{array}$} \\
\hline \hline 1. & 2011 & 2 & $\begin{array}{l}\text { Watugajah } \\
\text { Mertelu }\end{array}$ \\
\hline 2. & 2012 & 11 & $\begin{array}{l}\text { Tegalrejo Watugajah } \\
\text { Mertelu }\end{array}$ \\
\hline 3. & 2013 & 81 & $\begin{array}{l}\text { Hargomulyo Mertelu } \\
\text { Ngalang Serut } \\
\text { Watugajah }\end{array}$ \\
\hline 4. & 2014 & 29 & $\begin{array}{l}\text { Hargomulyo Mertelu } \\
\text { Sampang } \\
\text { Tegalrejo Watugajah }\end{array}$ \\
\hline 5. & 2015 & 13 & Watugajah \\
\hline
\end{tabular}

Sumber : BPBD Kabupaten Gunungkidul (2016)

Berdasarkan Peta Kerentanan Gerakan Tanah Kecamatan Gedangsari Tahun 2013 yang dibuat oleh Dinas Perindustrian Perdagangan dan Koperasi Energi Sumber Daya Mineral (Disperindagkop ESDM) Kabupaten Gunungkidul, daerah dengan kerentanan gerakan tanah tingkat tinggi meliputi sebagian besar wilayah Desa Serut, Sampang, Watugajah, Tegalrejo, Mertelu, Hargomulyo dan bagian utara wilayah Desa Ngalang. Daerah dengan kerentanan gerakan tanah tingkat menengah meliputi sebagian kecil wilayah Desa
Serut, Sampang, Watugajah, Tegalrejo, Mertelu, Hargomulyo dan sebagaian besar wilayah Desa Ngalang. Kemudian daerah dengan kerentanan gerakan tanah tingkat rendah dan sangat rendah meliputi bagian selatan wilayah Desa Ngalang.

Sistem Informasi Pertanahan (SIP) adalah suatu alatyang digunakan untuk pengambilan keputusan yang sah terhadap masalah administrasi dan ekonomi, serta sebagai alat bantu dalam perencanaan dan pengembangan yang terdiri dari basis data yang mengandung informasi lahan spasial tereferensi dan data-data yang terkait dengan hal tersebut pada satu pihak, prosedur dan teknik dalam pengambilan data tersistematik, updating, pengolahan dan distribusi data pada pihak lain. (Federation Internationale des Geometres dalam Nuraini dan Teguh 2010,1). Konsep, metode dan analisis SIP pada dasarnya sama dengan SIG. Perbedaanya adalah unit terkecil SIP berupa bidang tanah, sedangkan unit terkecil SIG bisa berupa zona atau batas wilayah administrasi (misalnya desa, kecamatan,kabupaten atau provinsi).

Dalam rangka penyediaan informasi pertanahan berbasis bencana tanah longsor di Kecamatan Gedangsari diperlukan peta ancaman, peta kerentanan, peta kapasitas dan peta risiko bencana tanah longsor, namun peta-peta tersebut belum tersedia. Apakah di Kecamatan Gedangsari tersedia data yang diperlukan untuk membuat peta-peta tersebut? Kemudian bagaimana upaya yang dilakukan untuk memadukan informasi bencana tanah longsor dengan informasi pertanahan?

Penelitian ini akan mencoba menggambarkan sebaran tingkat ancaman, kerentanan, kapasitas dan risiko bencana tanah longsor di Kecamatan Gedangsari dalam bentuk peta dengan skala 1: 50.ooo. Selanjutnya juga akan menggambarkan distribusi spasial bidang tanah terdaftar dan Titik Dasar Teknik pada berbagai tingkat ancaman, kerentanan, kapasitas dan risiko bencana tanah longsor di wilayah tersebut. 


\section{B. Tinjauan Pustaka}

\section{Bencana}

Definisi bencana menurut Undang Undang Nomor 24 Tahun 2007 tentang Penanggulangan Bencana adalah peristiwa atau rangkaian peristiwa yang mengancam dan mengganggu kehidupan dan penghidupan masyarakat yang disebabkan baik oleh faktor alam dan/atau non-alam maupun faktor manusia sehingga mengakibatkan timbulnya korban jiwa manusia, kerusakan lingkungan, kerugian harta benda dan dampak psikologis. Bencana terjadi karena adanya interaksi antara bahaya dan kerentanan serta adanya pemicu. Bahaya dan kerentanan menentukan adanya risiko bencana.

Risiko Bencana (Disaster Risk) adalah interaksi antara tingkat kerentanan daerah dengan ancaman bahaya yang ada. Semakin tinggi bahaya, kerentanan dan ketidakmampuan, akan semakin besar pula risiko bencana yang dihadapi (Nurjanah dkk. 2012, 18). Penilaian risiko melibatkan beberapa faktor yang saling terkait yaitu faktor bahaya/ ancaman (hazard), faktor kerentanan (vulnerability) dan faktor kemampuan (capacity) yang dinyatakan dalam persamaan:

$$
R=H \times V / C
$$

Keterangan :

R: Risk / Risiko

H: Hazard / Bahaya

V: Vulnerability/ Kerentanan

C: Capacity/ Kemampuan

Bahaya atau ancaman adalah suatu fenomena alam atau buatan yang mempunyai potensi mengancam kehidupan manusia, kerugian harta benda dan kerusakan lingkungan. Proses perubahan bumi secara dinamis dipandang sebagai potensi ancaman bahaya bagi manusiayang tinggal di atasnya (Nurjanah dkk. 2012, 15). Bahaya diklasifikasikan menjadi tiga yaitu natural hazard, technological hazard dan context hazard (Smith 1991 dalam Westen 2011, 75).

Kerentanan merupakan suatu kondisi dari suatu komunitas atau masyarakat yang mengarah atau menyebabkan ketidakmampuan dalam menghadapi ancaman bahaya. Tingkat kerentanan dapat ditinjau dari kerentanan fisik (infrastruktur), sosial kependudukan dan ekonomi (Nurjanah dkk. 2012, 17). Kerentanan terkait erat dengan elements at risk, yaitu semua benda, orang, hewan, fasilitas, kegiatan ekonomi, proses layanan masyarakat dan lingkungan yang dapat terkena dampak negatif dari suatu ancaman bahaya di wilayah tertentu, baik langsung maupun tidak langsung. Contoh element at risk di bidang pertanahan adalah Titik Dasar Teknik, bidang tanah terdaftar, tanda batas, dan Sertipikat Hak Atas Tanah.

Kapasitas menurut UN-ISDR 2004 dalam C. v. Westen (2011) adalah kombinasi dari seluruh kekuatan dan sumberdaya masyarakat atau organisasi untuk dapat mengurangi tingkat risiko bencana atau dampak suatu bencana.

\section{Tanah Longsor}

Tanah longsor merupakan salah satu bencana yang berasal dari natural hazards (geologic), yaitu jenis gerakan massa tanah atau batuan maupun percampuran dari keduanya, menuruni atau keluar lereng akibat terganggunya kestabilan tanah atau batuan penyusun lereng (Nurjanah dkk 2012, 25). Menurut Direktorat Vulkanologi dan Mitigasi Bencana Geologi (2005), tanah longsor dapat terjadi karena faktor alam dan faktor manusia sebagai pemicu terjadinya tanah longsor, yaitu : (a) Faktor Alam dan (b) Manusia. Kondisi alam yang menjadi faktor utama terjadinya longsor antara lain: (1) Kondisi geologi: batuan lapuk, kemiringan lapisan, sisipan lapisan batu lempung, lereng yang terjal yang diakibatkan oleh struktur sesar dan kekar (patahan dan lipatan), gempa bumi, stratigrafi dan gunung api, lapisan batuan yang kedap air miring ke lereng yang berfungsi sebagai bidang longsoran, adanya retakan karena proses alam (gempa bumi, tektonik); (2) Keadaan tanah: erosi dan pengikisan, adanya daerah longsoran lama, ketebalan tanah 
pelapukan bersifat lembek, butiran halus, tanah jenuh karena air hujan; (3) Iklim: curah hujan yang tinggi, air (hujan di atas normal); (4) Keadaan topografi: lereng yang curam; (5) Keadaan tata air: kondisi drainase yang tersumbat, akumulasi massa air, erosi dalam, pelarutan dan tekanan hidrostatika, susut air cepat, banjir, aliran bawah tanah pada sungai lama; (6) Tutupan lahan yang mengurangi tahan geser, misal lahan kosong, semak belukar di tanah kritis. Ulah manusia yang tidak bersahabat dengan alam dan dapat menimbulkan terjadinya tanah longsor antara lain: (1) Pemotongan tebing pada penambangan batu di lereng yang terjal; (2) Penimbunan tanah urugan di daerah lereng; (3) Kegagalan struktur dinding penahan tanah; (4) Perubahan tata lahan seperti penggundulan hutan menjadi lahan basah yang menyebabkan terjadinya pengikisan oleh air permukaan dan menyebabkan tanah menjadi lembek; (5) Budidaya kolam ikan dan genangan air di atas lereng; (6) Sistem pertanian yang tidak memperhatikan irigasi yang aman; (7) Pengembangan wilayah yang tidak diimbangi dengan kesadaran masyarakat, sehingga Rencana Untuk Tata Ruang (RUTR) tidak ditaati yang akhirnya merugikan sendiri; (8) Sistem drainase daerah lereng yang tidak baik yang menyebabkan lereng semakin terjal akibat penggerusan oleh air saluran di tebing; (9) Adanya retakan akibat getaran mesin, ledakan, beban massa yang bertambah dipicu beban kendaraan, bangunan dekat tebing, tanah kurang padat karena material urugan atau material longsoran lama pada tebing; (10) Terjadinya bocoran air saluran dan luapan air saluran.

Berdasarkan karakteristik longsoran, ada delapan jenis longsor yaitu Rotational Slide (longsoran rotasi), Translational Slide (longsoran translasi), Rock Block Slide (longsoran blok), Rockfall (runtuhan batu), Debrisflow (aliran debris), Debris Avalanche (debris bahan rombakan), Earth Flow (aliran tanah) dan Flowslide (aliran longsoran) (Westen 2011, 130).

\section{Metode Penelitian}

\section{Jenis dan Sumber Data}

Jenis data dalam penelitian ini meliputi data primer dan data sekunder. Data primer terdiri dari batas administrasi dusun yang diperoleh melalui survei di Kantor Desa se-kecamatan Gedangsari serta sampel kejadian longsor di Kecamatan Gedangsari yang diperoleh melalui observasi di lokasi kejadian longsor. Sedangkan data sekunder meliputi tingkat kerentanan gerakan tanah dan distribusinya di kecamatan Gedangsari yang diperoleh dari Peta Kerentanan Gerakan Tanah kecamatan Gedangsari Tahun 2013 Disperindagkop ESDM kabupaten Gunungkidul dengan skala 1: 25.0oo; bidang tanah terdaftar dan Titik Dasar Teknik beserta distribusinya di kecamatan Gedangsari yang diperoleh dari Peta Pendaftaran Tanah dan Peta Dasar Teknik Kantor Pertanahan kabupaten Gunungkidul; kondisi fisik wilayah dan kependudukan Kecamatan Gedangsari, meliputi jenis tanah, jenis batuan/kondisi geologi, kemiringan lereng, kondisi morfologi, curah hujan, penggunaan tanah, jumlah penduduk, kepadatan penduduk, jumlah kepala keluarga, jumlah rumah tangga miskin, fasilitas sosial ekonomi, fasilitas kesehatan dan kesiapsiagaan masyarakat. Data-data tersebut diperoleh dari laporan desa se-kecamatan Gedangsari dan dokumen kecamatan Gedangsari dalam Angka Tahun 2013, Laporan Akhir Penyusunan Peta Tingkat Kerentanan Gerakan Tanah dan Peta Tingkat Risiko Gerakan Tanah di kecamatan Gedangsari Tahun 2013 Disperindagkop ESDM kabupaten Gunungkidul.

\section{Alur Penelitian}

Kegiatan penelitian secara garis besar dibagi menjadi tiga tahapan yaitu tahap persiapan, tahap pelaksanaan dan tahap penyelesaian.

Tahap persiapan meliputi studi pustaka terkait dengan bencana tanah longsor, informasi pertanahan dan wilayah penelitian; mempersiapkan peta administrasi penelitian; menginventarisasi 
data dan peta yang dibutuhkan; mengumpulkan data; membuat peta tematik bencana yang terdiri dari peta ancaman, peta kerentanan, peta kapasitas dan peta risiko bencana tanah longsor; standarisasi peta tematik pertanahan, yaitu Peta Pendaftaran Tanah dan Peta Dasar Teknik. Peta Pendaftaran tanah di wilayah Kecamatan Gedangsari selanjutnya disebut Peta Bidang Tanah Terdaftar.

Tahap pelaksanaan meliputi overlay peta tematik bencana tanah longsor dan peta tematik pertanahan beserta analisis peta hasilnya. Overlay peta tersebut terdiri dari Peta Ancaman Bencana Tanah Longsor dengan Peta Bidang Tanah Terdaftar; Peta Kerentanan Bencana Tanah Longsor dengan Peta Bidang Tanah Terdaftar; Peta Kapasitas Masyarakat Terhadap Bencana Tanah Longsor dengan Peta Bidang Tanah Terdaftar; Peta Risiko Bencana Tanah Longsordengan Peta Bidang Tanah Terdaftar; Peta Ancaman Bencana Tanah Longsor dengan Peta Dasar Teknik; Peta Kerentanan Bencana Tanah Longsor dengan Peta DasarTeknik; Peta Kapasitas Bencana Tanah Longsor dengan Peta DasarTeknik; Peta Risiko Bencana Tanah Longsor dengan Peta Dasar Teknik.

Tahap penyelesaian meliputi penyajian informasi pertanahan berbasis bencana tanah longsor, pemanfaatan informasi pertanahan berbasis bencana tanah longsor di bidang pertanahan serta kesimpulan dan saran.

\section{Teknik Pengolahan dan Analisis Data}

Pengolahan data dilaksanakan dengan teknik pembobotan dan overlay. Setelah dilakukan overlay, tahap selanjutnya adalah analisis hasil penelitian. Teknik pembobotan dilakukan dalam rangka pembuatan peta tematik bencana tanah longsor di Kecamatan Gedangsari yang meliputi peta ancaman, peta kerentanan, peta kapasitas dan peta risiko bencana tanah longsor. Pembobotan diberikan sesuai dengan unsur penentu peta risiko yaitu ancaman, kerentanan dan kapasitas.

Unsur kerentanan dan kapasitas mempunyai beberapa variabel. Masing-masing variabel tersebut mempunyai indikator dan diberi bobot sesuai dengan besarnya pengaruh terhadap risiko terjadinya bencana tanah longsor. Besarnya bobot dari rentang o sampai dengan 3. Masing-masing indikator dispesifikasikan menjadi 3, dan diberikan skor dari 1 sampai dengan 3. Nilai akhir dari pembobotan ini adalah hasil kali antara bobot dan skor pada masing-masing indikator. Tabel pembobotan variabel penentu peta risiko bencana tanah longsor disajikan pada Lampiran 2.

Penilaian risiko bencana tanah longsor dihitung dengan mengalikan nilai ancaman dengan nilai kerentanan setelah dibagi dengan nilai kapasitas. Untuk menentukan klasifikasi risiko bencana tanah longsor ditentukan dengan metode equal interval yaitu membagi data kedalam kelompok dengan rentang nilai yang sama antar kelasnya (Prahasta 2002, 111). Setelah skor akhir pembobotan diperoleh, kemudian dibuat peta ancaman, peta kerentanan, peta kapasitas dan peta risiko dengan memanfaatkan software ArcGIS. Selanjutnya, dilakukan overlay dengan Peta Pendaftaran Tanah dan Peta Dasar Teknik. Tahap selanjutnya adalah analisis peta hasil overlay dan analisis tabel hasil pengolahan data untuk menyajikan informasi pertanahan berbasis bencana tanah longsor di Kecamatan Gedangsari. Informasi pertanahan berbasis bencana tanah longsor dimanfaatkan untuk mendukung peran Badan Pertanahan Nasional.

\section{Pembuatan Peta Tematik Benacana Tanah Longsor}

\section{Peta Ancaman}

Ancaman adalah suatu fenomena alam atau buatan yang mempunyai potensi mengancam kehidupan manusia, kerugian harta benda dan kerusakan lingkungan. Unsur ancaman dinilai dengan indikator Peta Kerentanan Gerakan Tanah yang dikeluarkan oleh Disperindagkop ESDM Kabupaten Gunungkidul Tahun 2013. Hal ini berdasarkan pedoman Nasional Pengkajian Risiko Bencana Tahun 2012, bahwa pembuatan peta risiko 
bencana disarankan memanfaatkan peta ancaman yang sudah dikeluarkan oleh Kementerian/ Lembaga terkait. Untuk jenis bencana longsor menggunakan peta ancamanyang dikeluarkan oleh oleh Kementerian Energi Sumber Daya Mineral (ESDM) (Kurniawan dkk. 2012, 31). Zona keren- ancaman juga melakukan transformasi koordinat dari UTM ke TM-3. Peta dasar yang digunakan adalah Peta Administrasi Kecamatan Gedangsari. Hasil konversi Peta Kerentanan Gerakan Tanah Kecamatan Gedangsari disajikan dalam Peta Ancaman Bencana Tanah Longsor pada Gambar 1. tanan gerakan tanah pada Peta Kerentanan Gerakan Tanah dijadikan menjadi 3 kelas ancaman yaitu rendah, sedang dan tinggi. Pada penilaian unsur ancaman, indikator ancaman diberi bobot 3 kemudian dusun dengan tingkat ancaman rendah diberi skor 1 , skor 2 pada dusun dengan tingkat ancaman sedang dan skor 3 pada pada dusun dengan tingkat ancaman tinggi. Nilai ancaman setiap dusun adalah bobot indikator dikalikan dengan skor masing-masing dusun.

Kerentanan gerakan tanah Kecamatan Gedangsari dibagi

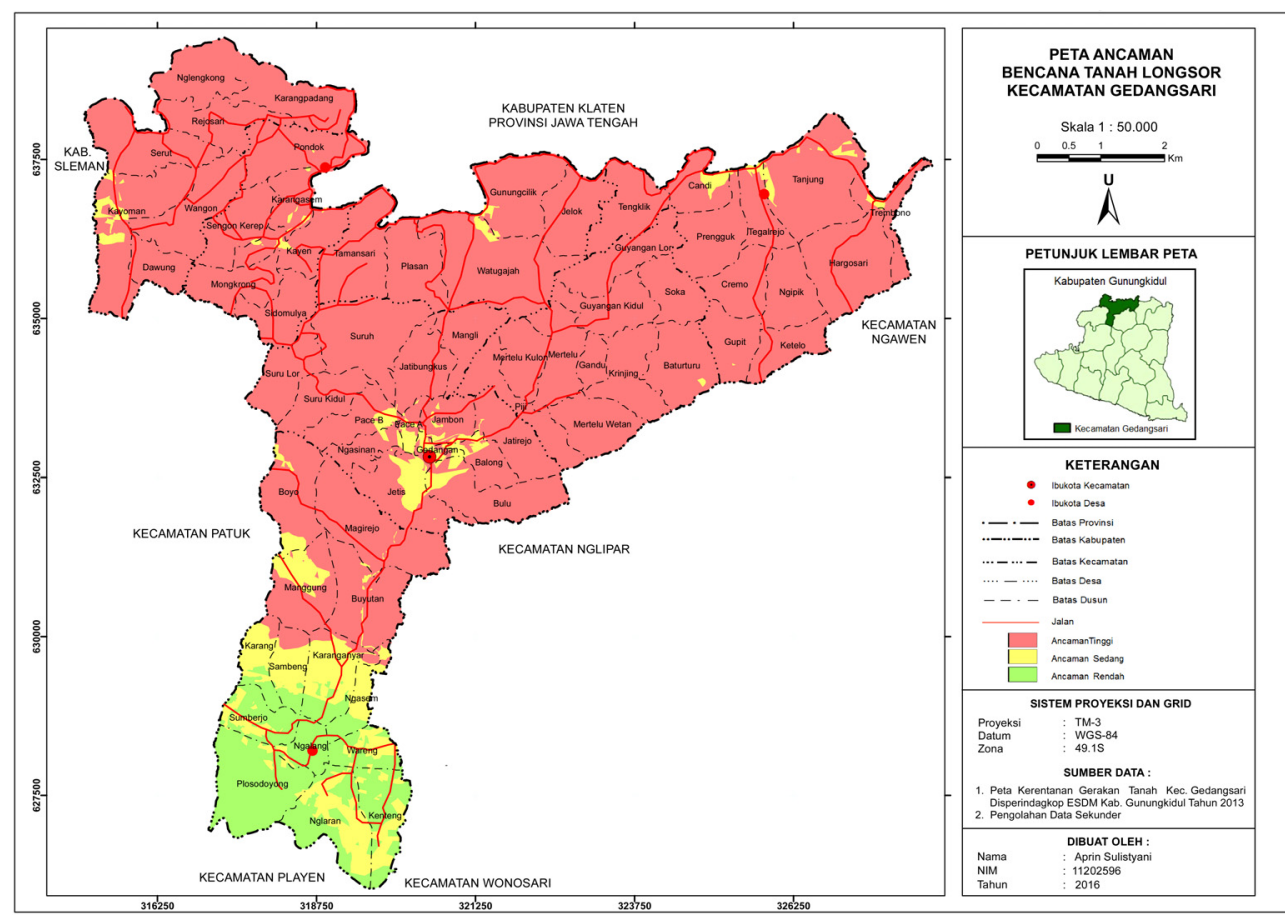
menjadi empat zona yaitu zona kerentanan gerakan tanah sangat rendah, rendah, menengah dan tinggi. Untuk menentukan kelas ancaman, nilai dari keempat zona kerentanan gerakan tanah tersebut dijadikan menjadi 3 kelas ancaman sesuai kriteria berikut :

Tabel 2. Konversi Zona Kerentanan Gerakan Tanah ke Kelas Ancaman

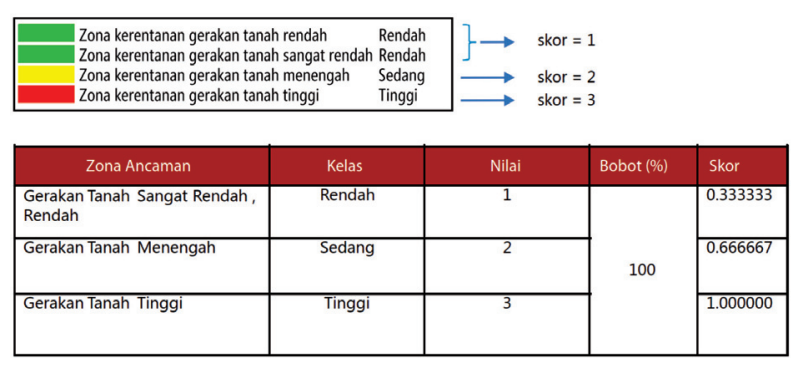

Sumber: BNPB $(2012,33)$

Pembuatan Peta Ancaman Bencana Tanah Longsor Kecamatan Gedangsari, selain dengan mengkonversi zona kerentanan menjadi kelas

Gambar i. Peta Ancaman Bencana Tanah Longsor Kecamatan Gedangsari

Peta Ancaman Bencana Tanah Longsor Kecamatan Gedangsari menunjukkan bahwa daerah yang termasuk dalam tingkat ancaman tinggi meliputi sebagian besar wilayah Desa Serut, Sampang, Watugajah, Tegalrejo, Mertelu, dan Hargomulyo, serta bagian utara wilayah Desa Ngalang. Daerah dengan tingkat ancaman sedang meliputi sebagian kecil wilayah Desa Serut, Sampang, Watugajah, Tegalrejo, Mertelu dan Hargomulyo, serta sebagaian besar wilayah Desa Ngalang. Sementara daerah dengan tingkat ancaman rendah hanya di bagian selatan wilayah Desa Ngalang.

Berdasarkan Laporan Akhir Penyusunan Peta Tingkat Kerentanan Gerakan Tanah di Kecamatan Gedangsari Disperindagkop ESDM Kabupaten Gunungkidul Tahun 2013, daerah dengan tingkat ancaman tinggi secara umum berada pada kondisi 
kelerengan yang curam, yaitu berada di bagian tengah sampai bagian utara wilayah Kecamatan Gedangsari. Batuan penyusun zona ini pada umumnya adalah anggota Formasi Kebobutakyang terdiri dari batupasir, serpih, tuf, aglomerat dan andesit basaltic; Formasi Semiliryang tersusun oleh breksi tuf yang berselang-seling dengan breksi batuapung, tuf dasit dan tuf andesit, serta batulempung tufan dan Formasi Nglanggran tersusun oleh breksi volkanik, aglomerat, breksi aliran lava, dan tuf. Tanah hasil pelapukan batuan pada umumnya tebal dengan kekar atau retakan-retakan yang cukup banyak. Dengan curah hujan cukup tinggi maka pelapukan dan ubahan batuan tersebut sangat intensif dan menghasilkan tanah yang tebal. Struktur geologi berupa kekar-kekar juga banyak terdapat pada batuan ini. Selain itu, aktivitas manusia berupa pemotongan lereng untuk membangun jalan dan pemukiman penduduk menyebabkan lereng menjadi tidak stabil. Akibatnya, masuknya air dapat menghilangkan daya ikat partikel penyusun lereng, akhirnya massa tanah tersebut dapat bergerak sebagai nendatan ataupun luncuran tanah dan bahan rombakan serta jatuhan material batuan. Gerakan tanah yang lama juga berpotensi untuk aktif kembali bergerak apabila ada pemicu seperti curah hujan yang tinggi, gempa, maupun aktivitas manusia.

Daerah dengan tingkat ancaman sedang secara umum mempunyai kemiringan lereng yang sedang dengan ketinggian yang cukup tinggi. Zona ini terdapat di sekitar zona kerentanan tinggi, umumnya pada lereng bagian atas lembah. Litologi penyusun di daerah ini berupa anggota Formasi Kebobutak, Semilir, Nglanggran dan Sambipituyang telah mengalami proses eksogenik sehingga membentuk tanah yang relatif tebal. Potensi gerakan tanah pada daerah ini cukup besar apabila ada pemicu seperti curah hujan yang tinggi maupun perubahan penggunaan tanah.

Daerah dengan tingkat ancaman rendah pada umumnya mempunyai kelerengan yang landai dan batuan penyusunnya relatif stabil meskipun tersusun oleh tuf, batupasir tufaan, napal tufaan, batugamping, dan konglomerat dan tanah hasil pelapukan relatiftebal. Gerakan tanah jarang terjadi, kalaupunada berupa nendatan dengan dimensiyang kecil. Kebanyakan terjadi di lembah sungai, karena pengaruh aliran sungai dan tebing pada jalan.

\section{Peta Kerentanan}

Kerentanan merupakan suatu kondisi dari suatu komunitas atau masyarakat yang mengarah atau menyebabkan ketidakmampuan dalam menghadapi ancaman bahaya. Tingkat kerentanan dapat ditinjau dari kerentanan fisik (infrastruktur), sosial kependudukan dan ekonomi (Nurjanah dkk. 2012, 17). Tingkat kerentanan dalam penelitian ini, terdiri dari komponen fisik, komponen kependudukan dan komponen ekonomi. Variabel kerentanan fisik terdiri dari kepadatan permukiman dan jarak ratarata dusun ke kantor desa. Variabel kerentanan kependudukan terdiri dari kepadatan penduduk, dan rasio jenis kelamin. Kemudian variabel kerentanan ekonomi meliputi persentase rumah tangga miskin dan persentase lahan produktif. Variabelvariabel kerentanan tersebut kemudian diwujudkan dalam bentuk Peta Kerentanan.

Berdasarkan pengolahan data kerentanan dari komponen fisik, Dusun Piji dan Mertelu Wetan memiliki kelas kerentanan fisik terendah karena persentase permukiman kurang dari 20\% dan jarak ke kantor desa kurang dari 1500 meter. Sementara persentase permukiman lebih dari $46 \%$ dan jarak ke kantor desa yang cukup jauh membuat Dusun Karang, Tengklik, Trembono, Mongkrong, Kayoman, Dawung dan Karangpadang memiliki kelas kerentanan fisik tertinggi.

Hasil pengolahan data kerentanan dari komponen kependudukan, menunjukkan 82.09\% dusun di Kecamatan Gedangsari memiliki kepadatan penduduk kurang dari 9 Jiwa/Ha dan rasio jenis kelamin 68\% - 112\%. Kelas kerentanan komponen kependudukan tertinggi dimiliki Dusun Gedangan dengan kepadatan penduduk 28 Jiwa/ 
Ha. Sementara rasio jenis kelamin tertinggi berada di Dusun Tamansari, Sidomulyo, Trembono dan Karangasem.

Hasil pembobotan data kerentanan dari komponen ekonomi perdusun di Kecamatan Gedangsari menggambarkan seluruh dusun di Kecamatan Gedangsari memiliki persentase lahan produktif lebih dari 20\% dengan persentase tertinggi sebesar 89.91\% di Dusun Bulu. Dusun Pondok memiliki kelas kerentanan ekonomi terendah karena persentase rumah tangga miskin hanya $22.89 \%$ dan merupakan dusun dengan persentase rumah tangga miskin paling sedikit di Kecamatan Gedangsari. Sementara 23.88\% dusun di Kecamatan Gedangsari memiliki kelas kerentanan ekonomi tertinggi dengan persentase lahan produktif dan persentase rumah tangga miskin lebih dari 6o\%.

Kelas kerentanan didapatkan dari penjumlahan kelas kerentanan komponen fisik, kependudukan dan ekonomi. Berdasarkan pengolahan data tersebut,

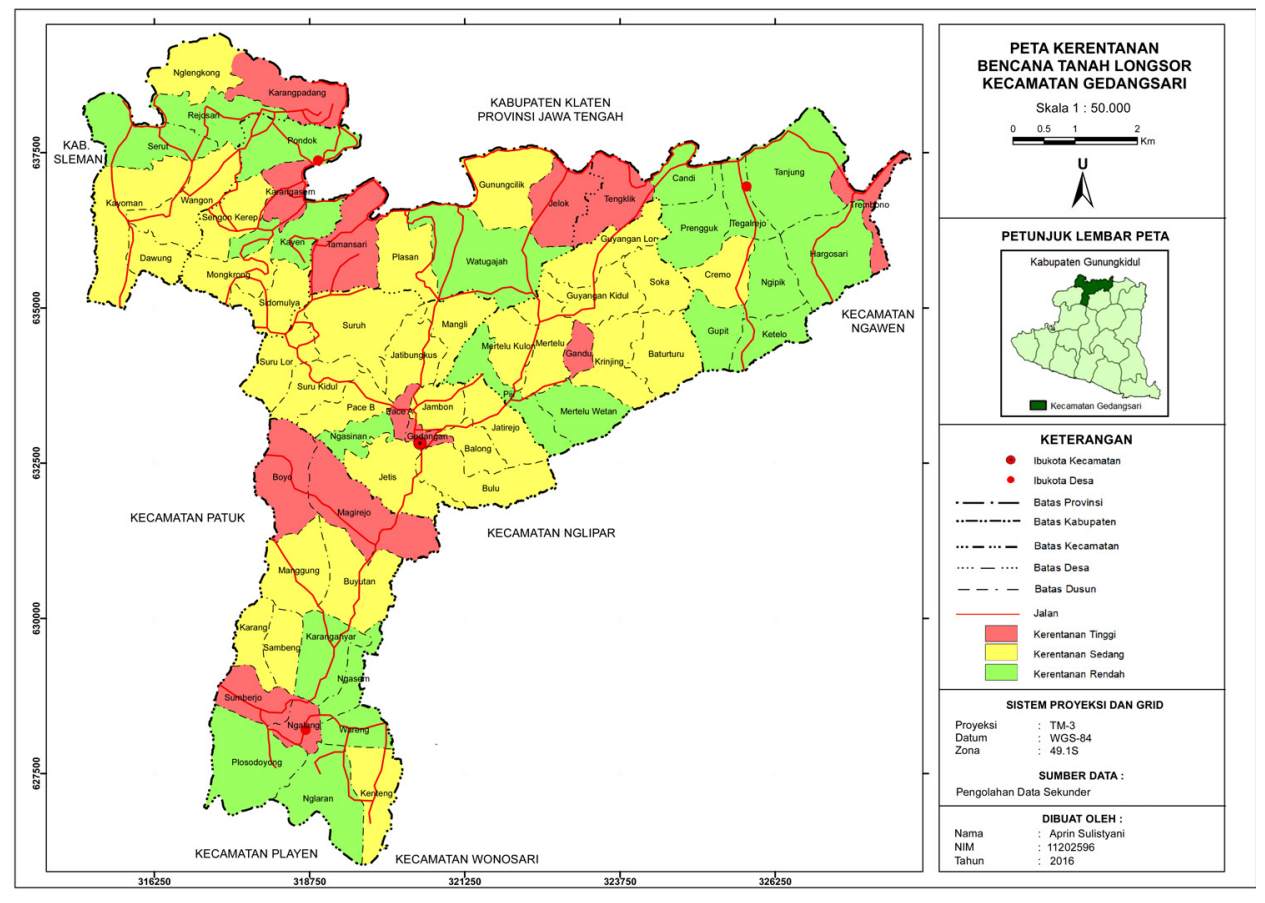
kelas kerentanan terendah adalah 4.70 di Dusun Rejosari dan Nglaran, kelas kerentanan tertinggi 6.70 di Dusun Gedangan dan Trembono. Selanjutnya, dibuat tiga rentang skor untuk menentukan kriteria kerentanan tinggi, sedang dan rendah dengan hasil sebagai berikut :

Tabel 3. Rentang Skor Kelas Kerentanan perdusun di Kecamatan Gedangsari

\begin{tabular}{|c|l|rr||}
\hline No. & Kiteria Kerentanan & \multicolumn{2}{|c|}{ Rentang Skor } \\
\hline \hline 1 & Tinggi & 6.04 & -6.70 \\
\hline 2 & Sedang & $5.37-6.03$ \\
\hline 3 & Rendah & $4.70-$ & -5.36 \\
\hline
\end{tabular}

Sumber: Pengolahan Data Sekunder Tahun 2016

Tingkat Kerentanan perdusun di Kecamatan
Gedangsari disajikan dalam Peta Kerentanan Bencana Tanah Longsor Kecamatan Gedangsari pada Gambar 2. Berdasarkan peta tersebut, wilayah dengan tingkat kerentanan tinggi berjumlah 13 dusun, tingkat kerentanan sedang 33 dusun dan tingkat kerentaan rendah 21 dusun. Kantor Desa Hargomulyo, Kantor Desa Ngalang dan Kantor Camat termasuk dalam wilayah dengan tingkat kerentanan tinggi.

\begin{abstract}
Gambar 2. Peta Kerentanan Bencana Tanah Longsor Kecamatan Gedangsari
\end{abstract}

\section{Peta Kapasitas}

Kapasitas menurut UN-ISDR 2004 dalam C. v. Westen (2011) adalah kombinasi dari seluruh kekuatan dan sumberdaya masyarakat atau organisasi untuk dapat mengurangi tingkat risiko bencana atau dampak suatu bencana. Tingkat kapasitas dalam penelitian ini ditentukan dari komponen kesiapsiagaan, fasilitas sosial ekonomi dan fasilitas kesehatan. Variabel kesiapsiagaan meliputi jalur evakuasi, tempat pengungsian, Early Warning System dan organisasi tanggap bencana. Variabel fasilitas sosial ekonomi terdiri dari jumlah pasar, jumlah sekolah dan persentase wilayah 
terlayani jalan. Kemudian variabel fasilitas kesehatan meliputi jumlah rumah sakit, jumlah balai kesehatan, jumlah puskesmas, jumlah posyandu, jumlah apotik, jumlah tenaga medis dan jumlah tenaga paramedis. Variabel-variabel kapasitas diwujudkan dalam Peta Kapasitas.

Berdasarkan pengolahan data kapasitas dari komponen kesiapsiagaan di Kecamatan Gedangsari, Dusun Ngalang, Mertelu Kulon, Baturturu dan Serut memiliki kelas kesiapsiagaan tertinggi karena telah memiliki jalur evakuasi dan setidaknya tergabung dalam dua organisasi kebencanaan. Organisasi kebencanaan dimanfaatkan untuk memberikan pendidikan kebencanaan kepada masyarakat berkaitan dengan upaya mengurangi dan melindungi masyarakat dari dampak bencana.

Hasil pengolahan data kapasitas dari komponen fasilitas sosial ekonomi di Kecamatan Gedangsari menunjukkan bahwa Dusun Magirejo, Sambeng, Gandu, Soka, Guyangan Kidul, Gupit dan Ketelo memiliki kelas kapasitas fasilitas sosial ekonomi terendah. Hal tersebut disebabkan karena belum memiliki pasar dan sekolah, ditambah wilayah dusun yang terlayani jalan masih kurang dari 0.38\%. Kelas kapasitas fasilitas sosial ekonomi tertinggi dimiliki Dusun Ngalang dan Gedangan karena memiliki pasar dan sekolah setidaknya dua unit serta wilayah yang terlayani jalan lebih dari o.77\%.

Hasil pembobotan data kapasitas dari komponen fasilitas kesehatan perdusun di Kecamatan Gedangsari menunjukkan bahwa Dusun Mertelu memiliki kelas kapasitas fasilitas kesehatan tertinggi karena memiliki posyandu balita, posyandu lansia dan setidaknya memiliki dua tenaga paramedis. Sementara kelas terendah berada di 34 dusun yang hanya memiliki fasilitas kesehatan berupa posyandu balita.

Kelas kapasitas didapatkan dari penjumlahan kelas kesiapsiagaan, fasilitas sosial ekomoni dan fasilitas kesehatan. Berdasarkan pengolahan data kelas kapasitas, kelas kapasitas terendah adalah 4.10 dan tertinggi 6.46. Selanjutnya, dibuat tiga rentang skor untuk menentukan kriteria kapasitas tinggi, sedang dan rendah dengan hasil sebagai berikut:

Tabel 4. Rentang Skor Kelas Kapasitas perdusun di Kecamatan Gedangsari

\begin{tabular}{|c|l|rl||}
\hline \hline No. & Kiteria Kerentanan & \multicolumn{2}{|c|}{ Rentang Skor } \\
\hline \hline 1 & Tinggi & 5.69 & -6.46 \\
\hline 2 & Sedang & 4.90 & -5.67 \\
\hline 3 & Rendah & 4.10 & -4.89 \\
\hline
\end{tabular}

Sumber : Pengolahan Data Sekunder Tahun 2016

Tingkat Kapasitas perdusun di Kecamatan Gedangsari disajikan dalam Peta Kapasitas Masyarakat Terhadap Bencana Tanah Longsor Kecamatan Gedangsari pada Gambar 3. Berdasarkan peta tersebut, wilayah dengan tingkat kapasitas tinggi hanya meliputi Dusun Ngalang dan Gedangan. Dusun Ngalang merupakan pusat Desa Ngalang, sedang Desa Gedangan adalah pusat Desa Hargomulyo yang merupakan ibukota Kecamatan Gedangsari. Tingkat kapasitas sedang meliputi sebagian kecil Desa Serut, Sampang, Mertelu, Hargomulyo dan Ngalang. Kemudian Tingkat kapasitas rendah meliputi seluruh wilayah Desa Tegalrejo dan Watugajah, serta sebagian besar wilayah Desa Serut, Sampang, Mertelu, Hargomulyo dan Ngalang.

Peta Kapasitas Masyarakat Terhadap Bencana Tanah Longsor Kecamatan Gedangsari memperlihatkan bahwa kombinasi seluruh sumberdaya dan potensi yang dimiliki masyarakat di Kecamatan Gedangsari untuk mencegah, mengurangi, menanggapi dan segera pulih dari dampak bencana secara umum masih tergolong tingkat rendah. Sejumlah 52 dusun memiliki kapasitas rendah, 13 dusun memiliki kapasitas sedang dan hanya 2 dusun yang memiliki kapasitas tinggi. 


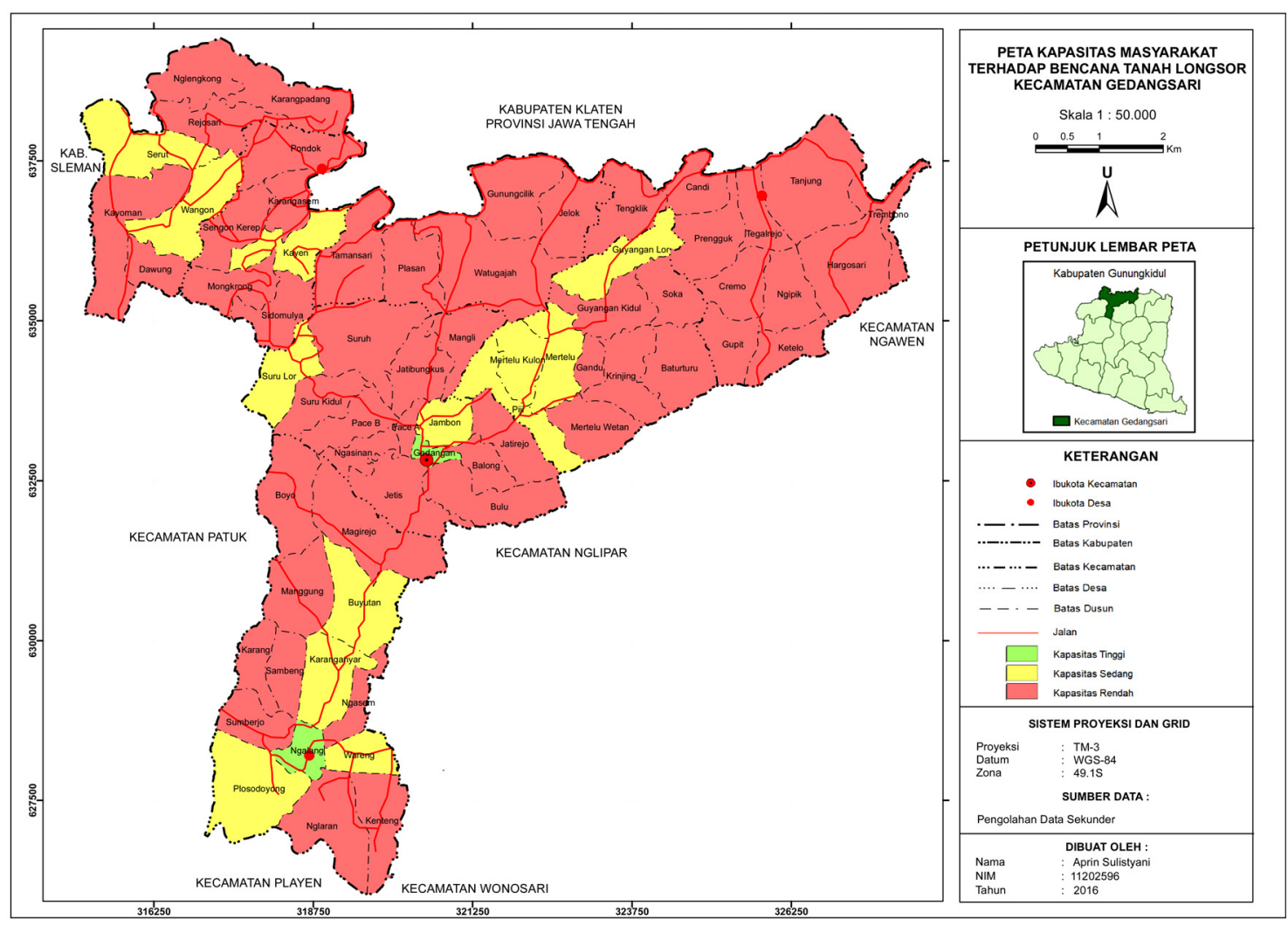

Gambar 3. Peta Kapasitas Masyarakat Terhadap Bencana Tanah Longsor Kecamatan Gedangsari

\section{Peta Risiko}

Risiko Bencana (Disaster Risk) adalah interaksi antara tingkat kerentanan daerah dengan ancaman bahaya yang ada. Semakin tinggi bahaya, kerentanan dan ketidakmampuan, akan semakin besar pula risiko bencana yang dihadapi (Nurjanah dkk. 2012, 18). Peta Risiko menggambarkan tingkat risiko bencana tanah longsor pada masing-masing dusun. Penghitungan kelas risiko pada penelitian ini, diawali dengan menghitung kelas ancaman pada masing-masing dusun berdasarkan Peta Ancaman dan Peta Administrasi Kecamatan Gedangsari. Penghitungan kelas ancaman, dilaksanakan dengan menghitung luas wilayah dengan tingkat ancaman tinggi, sedang dan rendah pada masing-masing dusun kemudian dipersentasekan terhadap luas wilayah dusun. Selanjutnya menghitung skor ancaman, dimana untuk tingkat ancaman tinggi diberi skor 3, sedang diberi skor 2 dan rendah diberi skor 1 . Kelas ancaman diperoleh dengan mengalikan skor tersebut dengan bobot ancaman 3.
Penghitungan kelas risiko dilaksanakan setelah diperoleh kelas ancaman yaitu dengan mengalikan kelas ancaman dengan kelas kerentanan setelah dibagi dengan kelas kapasitas. Hasil penghitungan kelas risiko perdusun di Kecamatan Gedangsari menunjukkan bahwa kelas kapasitas terendah adalah 3.17 di Dusun Plosodoyong dan tertinggi 13.46 di Dusun Karangpadang. Selanjutnya, dibuat tiga rentang skor untuk menentukan kriteria risiko tinggi, sedang dan rendah dengan hasil sebagai berikut:

Tabel 5. Rentang Kelas Risiko perdusun di Kecamatan Gedangsari

\begin{tabular}{|c|l|cc||}
\hline No. & Kiteria Kerentanan & \multicolumn{2}{|c|}{ Rentang Skor } \\
\hline \hline 1 & Tinggi & 10.04 & -13.46 \\
\hline 2 & Sedang & $6.61 \quad-\quad 10.03$ \\
\hline 3 & Rendah & $3.17-6.60$ \\
\hline
\end{tabular}

Sumber : Pengolahan Data Tahun 2016

Tingkat Risiko perdusun di Kecamatan Gedangsari disajikan dalam Peta Risiko Bencana 
Tanah Longsor pada Gambar 4. Sebanyak 41 dusun memiliki tingkar risiko tinggi dan menyebar di seluruh desa yang meliputi sebagian besar dusun di Desa Hargomulyo, Tegalrejo, Mertelu, Watugajah dan Sampang, serta sebagian kecil dusun di Desa Ngalang. Tingkat risiko sedang meliputi sebagian kecil dusun di Desa Hargomulyo, Tegalrejo, Mertelu, Watugajah, Sampang dan Ngalang. Sedangkan tingkat risiko rendah hanya meliputi 9 dusun yang semuanya berada di Desa Ngalang bagian selatan.

Bentuk kesiapsiagaan menghadapi risiko bencana diantaranya adalah menyediakan tempat pengungsian apabila diperlukan ketika terjadi bencana. Pemilihan Kantor Desa sebagai tempat pengungsian di wilayah penelitian adalah tindakan yang tepat karena dusun-dusun yang ditempati kantor desa tidak berada pada tingkat risiko tinggi. Selain faktor keamanan, kantor desa pada umumnya berdekatan dengan fasilitas kesehatan seperti puskesmas yang memudahkan penanganan pertolongan pertama pada korban bencana.

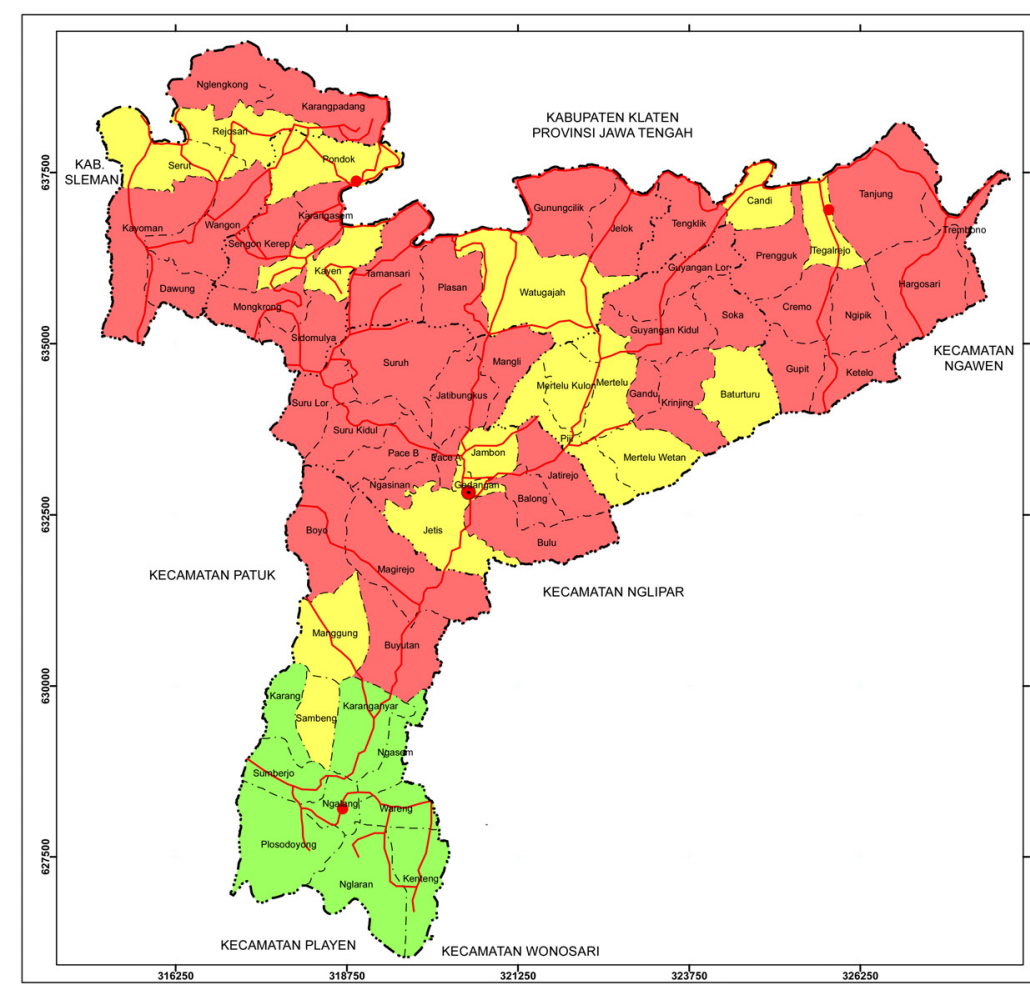

Gambar 4. Peta Risiko Bencana Tanah Longsor Kecamatan Gedangsari

\section{E. Posisi Keruangan Bidang Tanah} Terdaftar dan TDT pada Berbagai Tingkat Risiko Bencana Tanah Longsor

Peta tematik bencana tanah longsor di Kecamatan Gedangsari dipadukan dengan Peta Bidang Tanah Terdaftar dan Peta Dasar Teknik untuk menyediakan informasi pertanahan berbasis bencana tanah longsor di Kecamatan Gedangsari.

\section{Hasil Overlay Peta Tematik Bencana Tanah Longsor dengan Peta Bidang Tanah Terdaftar}

Hasil overlay Peta Ancaman dengan Peta Bidang Tanah Terdaftar di Kecamatan Gedangsari menunjukkan bahwa seluruh bidang tanah terdaftar di Desa Mertelu berada pada tingkat ancaman tinggi. Hampir seluruh bidang tanah terdaftar di Desa Tegalrejo, Watugajah, Serut, Sampang dan Hargomulyo juga berada pada tingkat ancaman tinggi. Hanya sebagian kecil bidang tanah terdaftaryang berada pada tingkat ancaman rendah yaitu di bagian utara Desa Tegalrejo dan Watu-

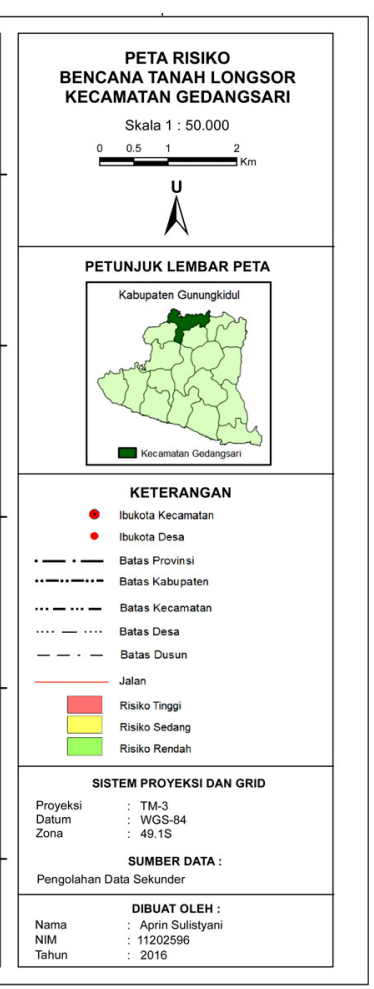
gajah, bagian tengah Desa Sampang dan Hargomulyo serta bagian barat Desa Serut. Bidang tanah terdaftar di Desa Ngalang dapat dikatakan sebagai aset pertanahan yang paling aman di Kecamatan Gedangsari karena sebagian besar berada pada tingkat ancaman rendah sampai sedang, hanya sebagian kecilyang berada pada tingkat ancaman tinggi, yaitu di bagian utara Desa Ngalang.

Sebaran bidang tanah terdaftar pada berbagai tingkatancaman bencana perlu diidentifikasi untuk mengantisipasi kemungkinan terjadinya bencana 
tanah longsor. Hal ini berkaitan dengan kegiatan administrasi pertanahan. Bidang tanah terdaftar dibuktikan dengan Sertipikat Hak Atas Tanah, apabila tanah tersebut tertimpa bencana maka akan lebih mudah diidentifikasi dibanding bidang tanah yang belum terdaftar karena telah tercatat di Kantor Pertanahan serta terjamin letak dan luasnya. Data dan informasi pada kegiatan administrasi pertanahan dapat mendukung upaya penanganan bencana selanjutnya, seperti identifikasi pemilik tanah, dan penghitungan kerugian.

Hasil Overlay Peta Kerentanan dengan Peta Bidang Tanah Terdaftar di Kecamatan Gedangsari menggambarkan sebagian besar tanah terdaftar di Desa Ngalang dan Tegalrejo berada pada tingkat kerentanan rendah. Sebagian besar tanah terdaftar di Desa Hargomulyo, Mertelu dan Sampang berada pada tingkat kerentanan sedang. Sementara di Desa Watugajah dan Serut, tanah terdaftar terdistribusi merata pada tingkat kerentanan sedang sampai tinggi. Tanah terdaftar pada tingkat kerentanan tinggi kemungkinan besar akan memiliki risiko bencana lebih tinggi dibanding pada kerentanan rendah dan sedang.

Hasil Overlay Peta Kapasitas dengan Peta Bidang Tanah Terdaftar di Kecamatan Gedangsari memperlihatkan bahwa bidang tanah terdaftar berada pada $77.61 \%$ dusun dengan tingkat kapasitas rendah, $19.40 \%$ dusun dengan tingkat kapasitas sedang dan 2.99\% dusun dengan tingkat kapasitas tinggi.

Pada wilayah dusun dengan tingkat kapasitas rendah, tanah terdaftar berjumlah 3.708 bidang dengan luas $5.710 .588 \mathrm{~m}^{2}$ atau baru $10.67 \%$ luas wilayah yang terdaftar. Wilayah tersebut meliputi seluruh dusun di Desa Tegalrejo dan Watugajah, serta sebagian besar dusun di Desa Serut, Sampang, Mertelu, Hargomulyo dan Ngalang. Peningkatan kapasitas masyarakat di dusun-dusun tersebut dapat dilaksanakan dengan mengoptimalkan peran organisasi kebencanaan untuk memberikan pen- didikan kebencanaan kepada masyarakat. Selain itu, diperlukan penambahan fasilitas sosial ekononi seperti pasar, sekolah dan jalan penghubung serta penambahan fasilitas kesehatan berupa posyandu lansia, tenaga medis, tenaga paramedis, pembangunan rumah sakit/balai pengobatan/puskesmas dan apotik.

Hasil overlay Peta Risiko dengan Peta Bidang Tanah Terdaftar di Kecamatan Gedangsari menggambarkan sebanyak 3.002 bidang tanah terdaftar terletak pada 41 dusun dengan tingkar risiko tinggi yang meliputi sebagian besar dusun di Desa Hargomulyo, Tegalrejo, Mertelu, Watugajah dan Sampang, serta sebagian kecil dusun di Desa Ngalang. Bidang tanah terdaftar pada tingkat risiko sedang pada sebagian kecil dusun di Desa Hargomulyo, Tegalrejo, Mertelu, Watugajah, Sampang dan Ngalang berjumlah 1.171 bidang. Sementara tanah terdaftar pada tingkat risiko rendah terletak pada 9 dusun di Desa Ngalang bagian selatan dengan jumlah 722 bidang.

Peran Kementerian ATR/BPN dalam mengurangi tingkat risiko bencana tanah longsor dapat dilaksanakan melalui legalisasi aset dengan rupiah murni seperti Prona dan Sertipikasi Tanah Petani. Wilayah dengan tingkat risiko bencana tanah longsor tinggi yang disebabkan kerentanan ekonomi berupa tingginya persentase rumah tangga miskin dan luasnya lahan produktif dapat ditunjuk sebagai lokasi sertipikasi tanah petani bekerjasama dengan Dinas Pertanian. Kantor Pertanahan melaksanakan pendaftaran tanah, selanjutnya sertipikat dapat diberdayakan bekerjasama dengan Dinas Pertanian. Tanah pertanianyang telah bersertipikat dapat dimanfaatkan sebagai sumber-sumber ekonomi masyarakat untuk penguatan modal usaha pertanian sehingga berkontribusi nyata dalam upaya peningkatan kesejahteraan masyarakat dan diharapkan dapat menurunkan tingkat kerentanan. 


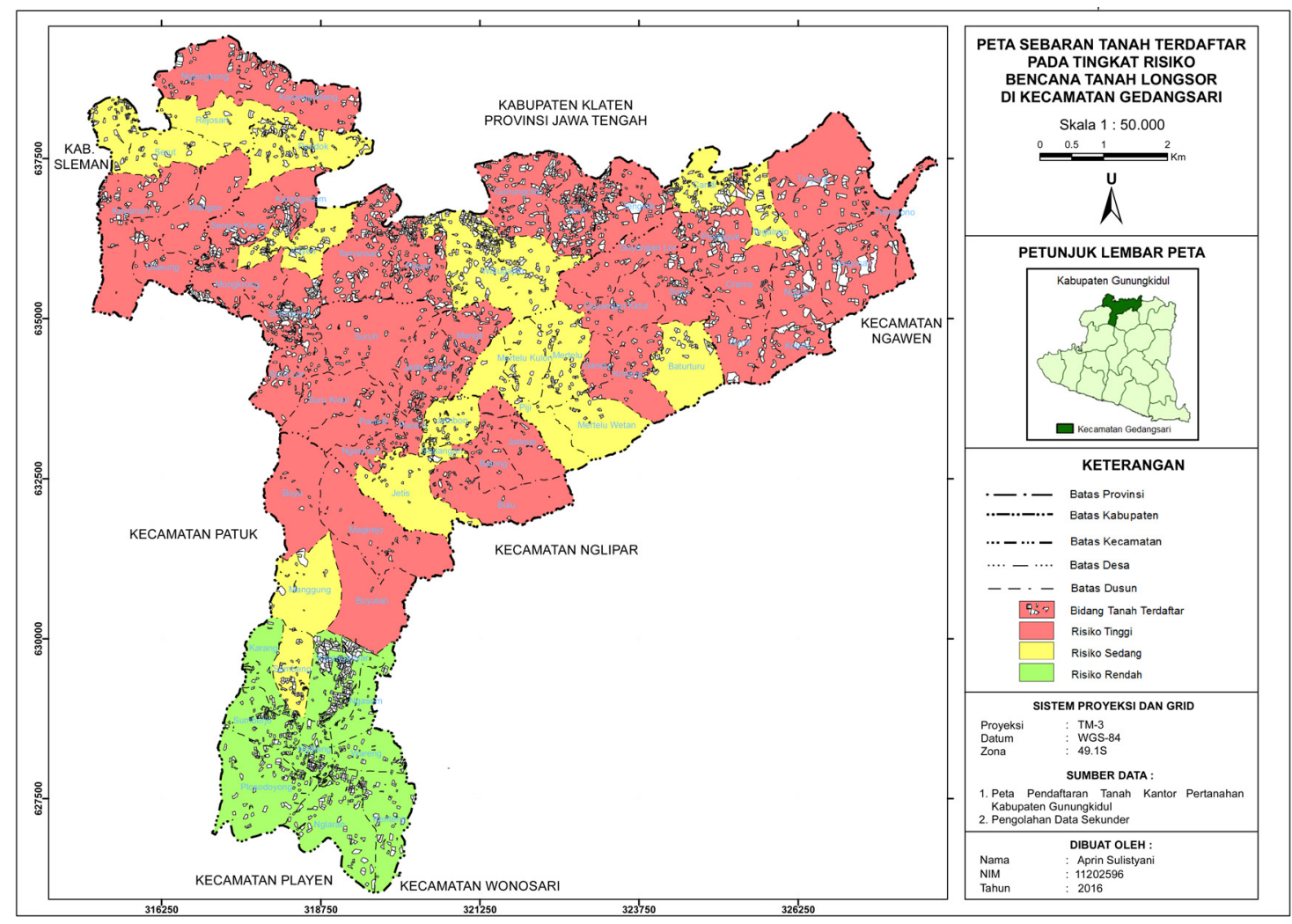

Gambar 5. Peta Bidang Tanah Terdaftar Pada Tingkat Risiko Kecamatan Gedangsari

\section{Hasil Overlay Peta Tematik Bencana} Tanah Longsor dengan Peta Bidang Tanah Terdaftar

Hasil Overlay Peta Ancaman dengan Peta Dasar Teknikdi Kecamatan Gedangsari menunjukkan distribusi TDT Orde 3 pada tingkat ancaman tinggi terdiri dari TDT 13.02.302 di Dusun Piji, TDT 13.02.301 di Dusun Jetis dan TDT 13.02.300 di Dusun Karanganyar. Sedangkan pada tingkat ancaman rendah terdiri dari TDT 13.02.299 di Dusun Ngalang dan TDT 13.02.298 di Dusun Wareng.

Distribusi TDT Orde 4 pada tingkat ancaman tinggi terdiri dari 22 TDT di Dusun Sidomulyo dan 3 TDT di Dusun Karanganyar Desa Ngalang. Pada tingkat ancaman sedang terdiri dari 2 TDT di Dusun Kenteng dan 37 TDT di Dusun Karanganyar. Pada tingkat ancaman rendah terdiri dari 7 TDT di Dusun Karanganyar, 20 TDT di Dusun, 12 TDT di Dusun Nglaran, dan 5 TDT di Dusun Kenteng.

Penyimpanan data pengukuran dan pemetaan TDT sangat penting dilaksanakan terutama pada wilayah dengan tingkat ancaman tinggi. Hal ini bertujuan agar dokumen terawat dan dapat digunakan sewaktu-waktu dibutuhkan. Data pengukuran dan pemetaan TDT meliputi buku tugu, Peta Dasar Teknik, data dan hasil hitungan serta peta rencana.

Hasil overlay Peta Kerentanan dengan Peta Dasar Teknik di Kecamatan Gedangsari menunjukkan bahwa TDT 13.02.301 adalah satu-satunya TDT Orde 3 yang terletak di wilayah dusun dengan tingkat kerentanan sedang. Sedangkan empat lainnya terletak di wilayah dusun dengan tingkat kerentanan rendah. Tidak ada TDT Orde 3 yang berada di wilayah dengan tingkat kerentanan tinggi.

Distribusi TDT Orde 4 merata pada wilayah penelitian dengan tingkat kerentanan rendah, sedang dan tinggi. TDT Orde 4 pada wilayah penelitian dengan tingkat kerentanan rendah berada di Dusun Karanganyar dan Nglaran. TDT Orde 4 pada wilayah penelitian dengan tingkat kerentanan sedang berada di Dusun Sidomulyo dan Kenteng, kemudian pada wilayah penelitian dengan tingkat kerentanan tinggi berada di Dusun Ngalang. 
Hasil overlay Peta Kapasitas dengan Peta Dasar Teknik di Kecamatan menunjukkan distribusi TDT Orde 3 dan Orde 4 merata di wilayah dengan tingkat kapasitas rendah hingga tinggi. Pada wilayah dengan tingkat kapasitas tinggi, meskipun dapat memperkecil tingkat risiko bencana, tetap diperlukan upaya pemeliharaan untuk menjaga keberadaan aset pertanahan yang berupa TDT tersebut. Pengetahuan pentingnya pemeliharaan TDT perlu disampaikan kepada masyarakat khususnya pemeliharaan secara fisik. Upaya pemeliharaan untuk menjaga kondisi fisik tugu dapat dilaksanakan dengan pengecatan, memperbaiki kerusakan dan menjaga dari kemungkinan tergesernya titik.

Hasil overlay Peta Risiko dengan Peta Dasar Teknik di Kecamatan Gedangsari menggambarkan bahwa TDT Orde 3 tersebar di wilayah dengan tingkat risiko rendah dan sedang. Sementara TDT Orde 4 tersebar di wilayah dengan tingkat risiko rendah dan tinggi. Pada tingkat risiko rendah, TDT Orde 3 tersebar di Desa Ngalang yang terdiri dari
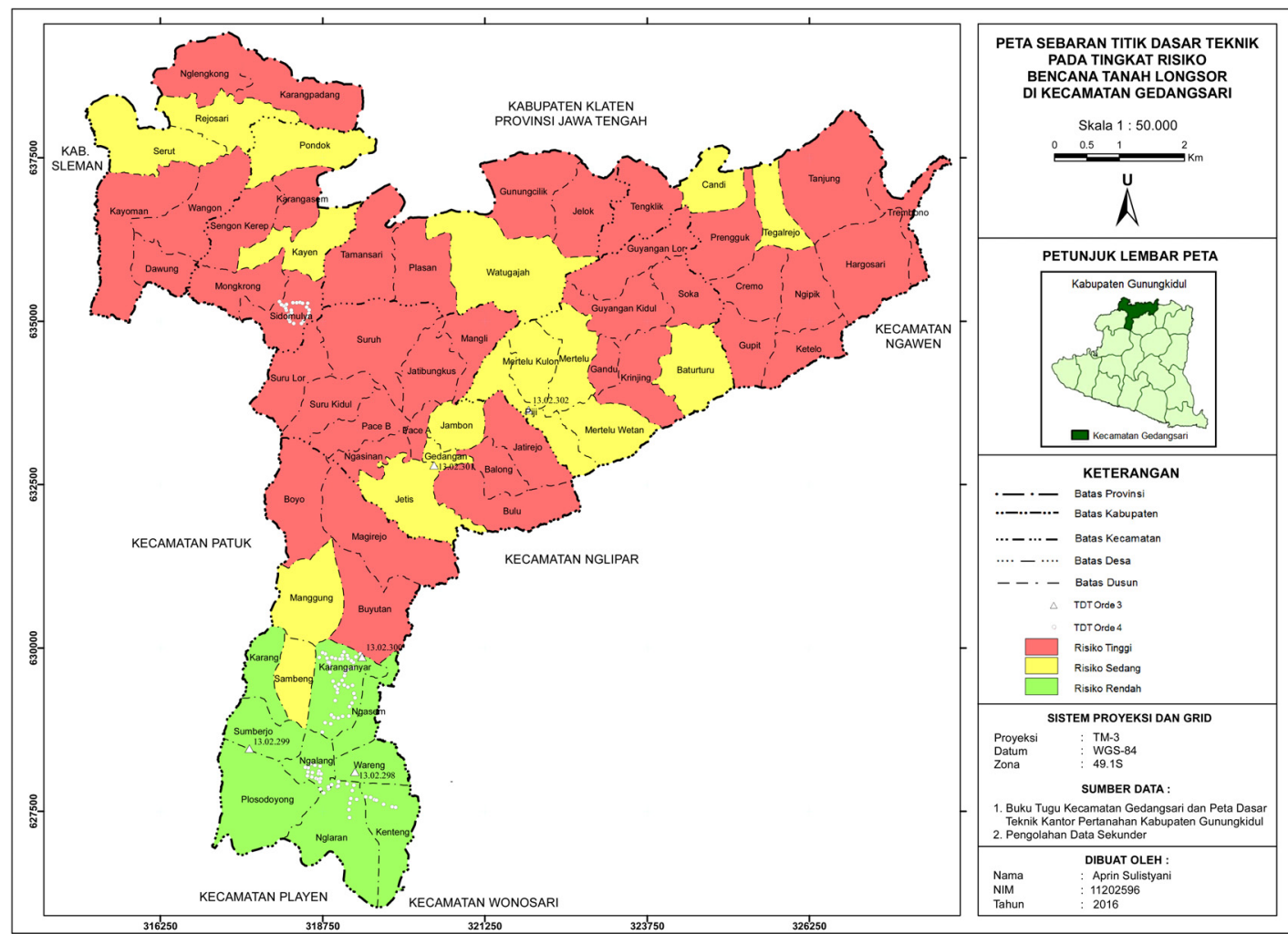
TDT 13.02.300, TDT 13.02.299 dan TDT 13.02.298. Sementara pada tingkat sedang, TDT 13.02.302 di Desa Mertelu dan TDT 13.02.301 di Desa Hargomulyo. Distribusi TDT Orde 4 pada tingkat risiko tinggi berjumlah 22 TDT di Dusun Sidomulyo dan 1TDT di Dusun Mongkrong Desa Sampang. Sisanya, sejumlah 87 TDT tersebar di Desa Ngalang pada tingkat risiko rendah yang terdiri dari 47 TDT di Dusun Karanganyar, 7 TDT di Dusun Kenteng, 20 TDT di Dusun Ngalang, 12 TDT di Dusun Nglaran.
Pemeliharaan TDT serta penyimpanan data pengukuran dan pemetaan sangat bermanfaat apabila akan dilaksanakan pengukuran dan pemetaan TDT baru. Data-data tersebut akan bermanfaat baik pada tahap pemasangan, pengukuran, pengolahan data maupun pemetaan TDT baru. Informasi jumlah dan sebaran TDT pada berbagai tingkat risiko dapat membantu penentuan lokasi TDT baru pada kondisi tanah yang relatif stabil dan tidak berada pada tanah dengan kemiringan yang curam. Peta Sebaran Titik Dasar Teknik pada Tingkat Risiko Bencana Tanah Longsor di Kecamatan Gedangsari disajikan pada Gambar

6.

Gambar 6. Peta Bidang Tanah Terdaftar Pada Tingkat Risiko Kecamatan Gedangsari

Informasi Pertanahan Berbasis Bencana Tanah Longsor dapat dimanfaatkan untuk mendukung pelaksanaan kegiatan manajemen bencana. Manajemen bencana merupakan upaya sistematis

\section{F. Manfaat Informasi Pertanahan Berbasis Bencana}


dan komprehensifyang bertujuan untuk mempersiapkan diri menghadapi bencana, menekan kerugian dan korban yang dapat timbul serta meningkatkan kesadaran semua pihak dalam masyarakat atau organisasi tentang bencana sehingga terlibat dalam proses penanganan bencana. Secara garis besar, manajemen bencana terdiri dari tiga tahap yaitu tahap pra-bencana, ketika terjadi bencana dan pasca-bencana. Tahap pra-bencana meliputi situasi tidak terjadi bencana dan situasi terdapat potensi bencana, dilaksanakan kegiatan pencegahan, mitigasi serta kesiapsiagaan. Pada saat terjadi bencana dilaksanakan tanggap darurat dan pasca-bencana dilakukan upaya rehabilitasi dan rekonstruksi.

Manajemen bencana dapat dilaksanakan melalui pembangunan wilayah berbasis pengurangan risiko bencana yang melibatkan berbagai disiplin dan kelompok kelembagaan yang berbeda. Kementerian ATR/BPN dapat berperan serta dengan melaksanakan pembangunan wilayah di bidang pertanahanyang sejalan dengan upaya pengurangan risiko bencana. Pembangunan tersebut dapat memanfaatkan informasi pertanahan berbasis bencana dalam upaya pelaksanaan fungsi Badan Pertanahan Nasional sebagaimana diatur dalam Peraturan Presiden Nomor 20 Tahun 2015 tentang Badan Pertanahan Nasional. Informasi pertanahan berbasis bencana tanah longsordapat dimanfaatkan antara lain untuk melaksanakan fungsi berikut:

a) Perumusan dan pelaksanaan kebijakan

di bidang pengaturan, penataan dan pengendalian kebijakan pertanahan;

Dalam rangka melaksanakan fungsi tersebut, informasi pertanahan berbasis bencana tanah longsor dapat digunakan oleh Kantor Pertanahan Kabupaten Gunungkidul sebagai bahan pertimbangan dalam penyusunan risalah dan peta pada kegiatan petimbangan teknis pertanahan dalam penerbitan izin lokasi, penetapan lokasi dan izin perubahan penggunaan tanah pada Subseksi Penatagunaan Tanah dan Kawasan Tertentu.
Pedoman Teknis Penggunaan dan Pemanfaatan Tanah yang diatur pada Peraturan Kepala Badan Pertanahan Nasional Republik Indonesia Nomor 2 Tahun 2011 mengharuskan penggunaan dan pemanfaatan tanah memenuhi azas keberlanjutan. Diantara butir ketentuan tersebut menyatakan bahwa daerah rawan bencana, seperti rawan longsor dan rawan banjir tidak boleh dipergunakan untuk kegiatan budidaya.

Dengan tersedianya informasi pertanahan berbasis bencana tanah longsor, kegiatan petimbangan teknis khususnya di Kecamatan Gedangsari diharapkan lebih dapat memenuhi azas keberlanjutan. Meskipun tidak bisa melarang pembangunan tempat tinggal dan segala jenis kegiatan budidaya pada wilayah-wilayah dengan tingkat ancaman tinggi setidaknya pemberian arahan penggunaan pada pertimbangan teknis pertanahan dapat mengendalikan aktivitas manusia yang dapat mempertinggi risiko bencana tanah longsor, seperti kegiatan pemotongan lereng untuk permukiman, kegiatan pertanian dan jalan.

\section{b) Perumusan dan pelaksanaan kebijakan di bidang pengadaan tanah;}

Pengadaan tanah bagi pembangunan untuk kepentingan umum antara lain adalah pengadaan tanah untuk pembangunan fasilitas keselamatan umum. Dalam rangka upaya mitigasi bencana, Badan Pertanahan Nasional dapat berperan dalam penyediaan tanah untuk relokasi yang dekat dengan lokasi bencana. Tanah tersebut akan dimanfaatkan untuk evakuasi korban dan harta benda masyarakat ketika terjadi bencana. Selain itu juga untuk menempatkan alat-alat penanganan korban bencana seperti alatalat berat dan mobil untuk evakuasi korban.

Dalam rangka menyediakan tanah relokasi yang dekat dengan lokasi bencana, informasi pertanahan berbasis bencana tanah logsor berperan penting sebagai bahan pertimbangan pengambilan keputusan. Informasi tersebut dapat digunakan sebagai bahan koordinasi bersama instansi lain seperti BPBD, Disperindagkop ESDM, Pemerintah 
Desa dan pihak lain yang terlibat. Setidaknya Kantor Pertanahan dapat memberi informasi status tanah yang ditetapkan sebagai tempat relokasi, apakah sudah terdaftar atau belum. Jika tanah yang direncanakan sudah terdaftar, dapat diidentifikasi pemilik, luas dan jenis hak tanahnya. Selanjutnya dapat dimanfaatkan pada proses pembebasan tanah, pemberian ganti rugi sampai pada pemberian hak baru tanah tersebut. Penyediaan tanah untuk relokasi korban bencana penting dilaksanakan pada tahap pra-bencana, mengingat proses pengadaan tanah tidak mudah dan memerlukan proses yang panjang. Jangan sampai ketika tengah terjadi bencana, penanganan korban terhambat karena tidak ada tempat relokasi.

\section{c) Pelaksanaan pemeliharaan data dan informasi di bidang pertanahan;}

Dalam rangka pengelolaan data dan informasi pertanahan, Badan Pertanahan Nasional harus memelihara aset untuk kepentingan pemeliharaan data. Titik Dasar Teknik merupakan salah satu aset pertanahan yang terpapar di Kecamatan Gedangsari. Dengan mengetahui sebaran Titik Dasar Teknik pada tingkatan ancaman, kerentanan, kapasitas dan risiko bencana tanah longsor, Kantor Pertanahan Kabupaten Gunungkidul dapat menentukan upaya pemeliharaan untuk menjaga aset tersebut dari kemungkinan tergeser atau hilang. Selain itu juga bertujuan untuk menjamin ketersediaan data pengukuran dan pemetaan TDT yang meliputi buku tugu, Peta DasarTeknik, data dan hasil hitungan serta peta rencana apabila sewaktu-waktu diperlukan. Hal tersebut bertujuan agar kegiatan seperti rekonstruksi batas tidak terhambat sehingga dapat menyajikan informasi pertanahan yang aktual.

\section{G. Penutup \\ 1. Kesimpulan}

Berdasarkan hasil penelitian dan analisis serta pembahasan yang telah dilakukan, maka dapat diambil kesimpulan sebagai berikut:

1) Pembuatan Peta Tematik Bencana Tanah
Longsordi Kecamatan Gedangsari yang meliputi Peta Ancaman, Peta Kerentanan, Peta Kapasitas dan Peta Risiko Bencana Tanah Longsor dilaksanakan dengan memetakan data ancaman, data kerentanan dan data kapasitas sebanyak 67 dusun di Kecamatan Gedangsari melalui pembobotan indikator di setiap komponen penyusunnya.

2) Penyediaan informasi pertanahan berbasis bencana tanah longsor di Kecamatan Gedangsari dilaksanakan dengan overlay Peta Tematik Bencana Tanah Longsor di Kecamatan Gedangsari dengan Peta Bidang Tanah Terdaftar dan Peta Dasar Teknik di Kecamatan Gedangsari sehingga menghasilkan peta-petayang memuat informasi baru yaitu :

a. Peta Sebaran Tanah Terdaftar pada Tingkat Ancaman, Kerentanan, Kapasitas dan Risiko Bencana Tanah Longsor di Kecamatan Gedangsari;

b. Peta Sebaran Titik Dasar Teknik pada Tingkat Ancaman, Kerentanan, Kapasitas dan Risiko Bencana Tanah Longsor di Kecamatan Gedangsari;

\section{Saran}

1) Kantor Pertanahan sebaiknya memiliki peta tematik bencana yang terdiri dari peta ancaman, peta kerentanan, peta kapasitas dan peta risiko, baik diperoleh dari instansi lain seperti BPBD dan Disperindagkop ESDM ataupun membuat sendiri. Peta tersebut berguna untuk menyediakan informasi pertanahan berbasis bencana sebagai bahan pertimbangan pengambilan kebijakan pertanahan dan bentuk partisipasi Kementerian ATR/BPN dalam upaya pengurangan risiko bencana. Kontribusi informasi tersebut bagi pelaksanaan fungsi Badan Pertanahan Nasional antara lain :

a. sebagai bahan koordinasi dalam rangka pengadaan tanah untuk pembangunan fasilitas keselamatan umum berupa penye- 
diaan tanah relokasi yang aman dan dekat dengan lokasi bencana;

b. sebagai bahan perencanaan kegiatan pemeliharaan TDT di lokasi bencana dan sekitarnya.

2) Penyediaan informasi pertanahan berbasis bencana tanah longsor di Kecamatan Gedangsari dalam penelitian ini masih terdapat beberapa keterbatasan, antara lain :

a. Informasi pertanahan yang disediakan sebatas bidang tanah terdaftar dan TDT, diharapkan ke depannya dapat dilengkapi dengan informasi pertanahan yang lain seperti nilai tanah. Selain itu, informasiyang disajikan baru menggambarkan distribusi bidang-bidang tanah terdaftar. Pada penelitian selanjutnya diharapkan dapat dilengkapi dengan bidang-bidang tanah yang belum terdaftar sehingga informasinya menjadi lebih lengkap.

b. Penyajian informasi pertanahan berbasis bencana tanah longsor masih dalam bentuk peta dan tabel, diharapkan ke depannya dapat disajikan dalam suatu aplikasi sistem informasi pertanahan berbasis bencana tanah longsor agar lebih mempermudah pengguna dalam mengakses informasi.

\section{H. Daftar Pustaka}

Pemerintah Kabupaten Gunungkidul Dinas Perindustrian Perdagangan Koperasi Energi Dan Sumber Daya Mineral Kabupaten Gunungkidul 2013, Laporan Akhir Penyusunan Peta Tingkat Kerentanan Gerakan Tanah Dan Peta Tingkat Risiko Gerakan Tanah Di Kecamatan Gedangsari.

—_, 2015, “40,9 Juta Jiwa Penduduk Indonesia Terpapar Ancaman Longsor", Gema BNPB, Vol. 6, No. 1, Mei 2015.

Badan Nasional Penanggulangan Bencana 2015, Kerangka Kerja Sendai untuk Pengurangan Risiko Bencana 2015 - 2030 , Jakarta.
Aditya, T 2014, "Peluang dan Tantangan Overlay Peta dan Aplikasi Geospasial Melalui Pemetaan Kolaboratif Berbasis SRGI 2013", Seminar dan Workshop ISI 2014, Pekanbaru.

Badan Pusat Statistik Kabupaten Gunungkidul 2015, Gunungkidul dalam Angka 2015., Badan Pusat Statistik, Kabupaten Gunungkidul.

Hasan, I 2009, Analisis Data Penelitian Dengan Statistik, Bumi Aksara, Jakarta.

Kurniawan, Ldkk. 2012, Pedoman Nasional Pengkajian Risiko Bencana untuk Rencana Penanggulangan Bencana, Badan Nasional Penanggulangan Bencana, Jakarta.

Nurjanah, dkk. 2012, Manajemen Bencana. Alfabeta, Bandung.

Peraturan Kepala Badan Pertanahan Nasional Republik Indonesia Nomor 2 Tahun 2011 tentang Pedoman Pertimbangan Teknis Pertanahan dalam Penerbitan Izin Lokasi, Penetapan Lokasi dan Izin Perubahan Penggunaan Tanah.

Prahasta, E 2002, Konsep - konsep Dasar Informasi Geografis, Informatika, Bandung.

Prahasta,E2002, TutorialArcGISDesktopUntuk Bidang Geodesi E Geomatika, Informatika, Bandung.

Raco, JR 2010, Metode Penelitian Kualitatif "Jenis, Karakteristik, dan Keunggulannya". Grasindo, Jakarta.

Ramli, S, Pedoman Praktis Manajemen Bencana (Disaster Management), Dian Rakyat, Jakarta.

Retnowati, RE 2014, "Pemetaan Risiko Bencana Tanah Longsor dan Prediksi Kerugian Petani (Studi di Desa Hargotirto Kecamatan Kokap Kabupaten Kulon Progo)”, Skripsi, Sekolah Tinggi Pertanahan Nasional.

Sudibyakto 2011, Manajemen Bencana Di Indonesia Ke Mana?, Gadjah Mada University Press, Yogyakarta.

Sugiyono 2008, Memahami Penelitian Kualitatif, Alfabeta, Bandung.

Sugiyono 2011, Metode Penelitian Kombinasi (Mixed Methods), Alfabeta, Bandung.

Undang-Undang Nomor 24 Tahun 2007 tentang Penanggulangan Bencana.

Westen, CV 2011, Multi Hazard Risk Assessment. University of Twente, Enschede. 

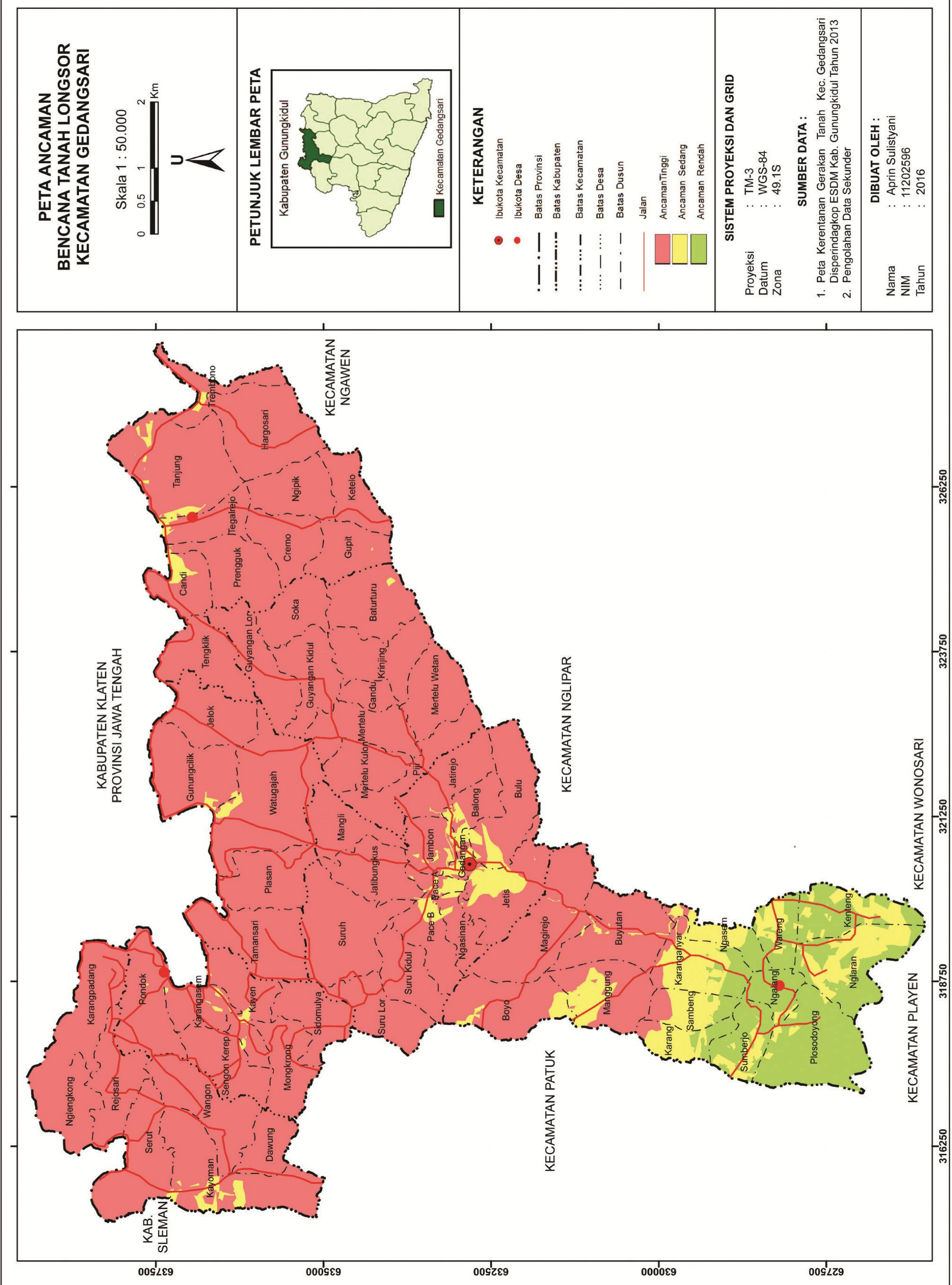

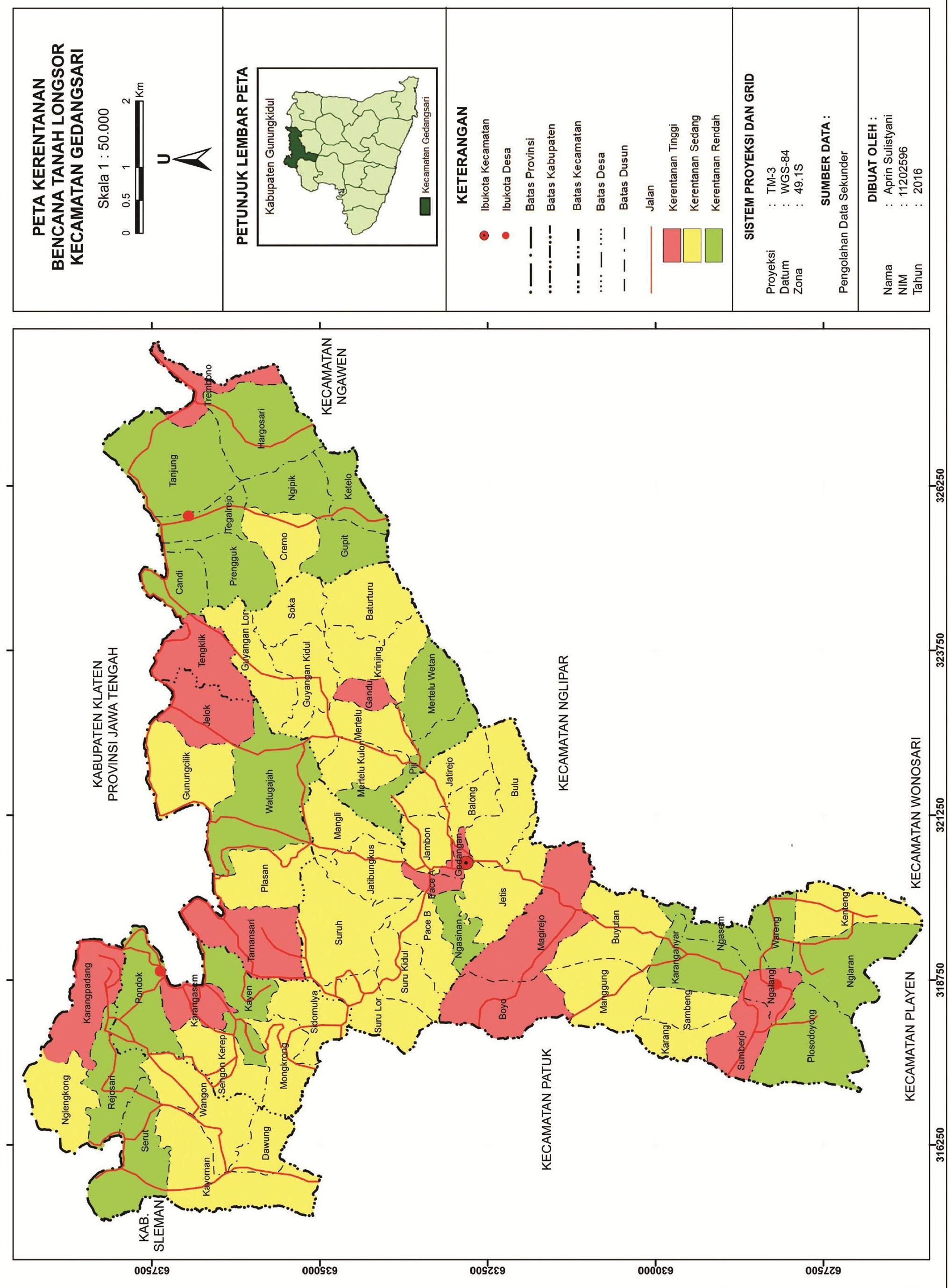

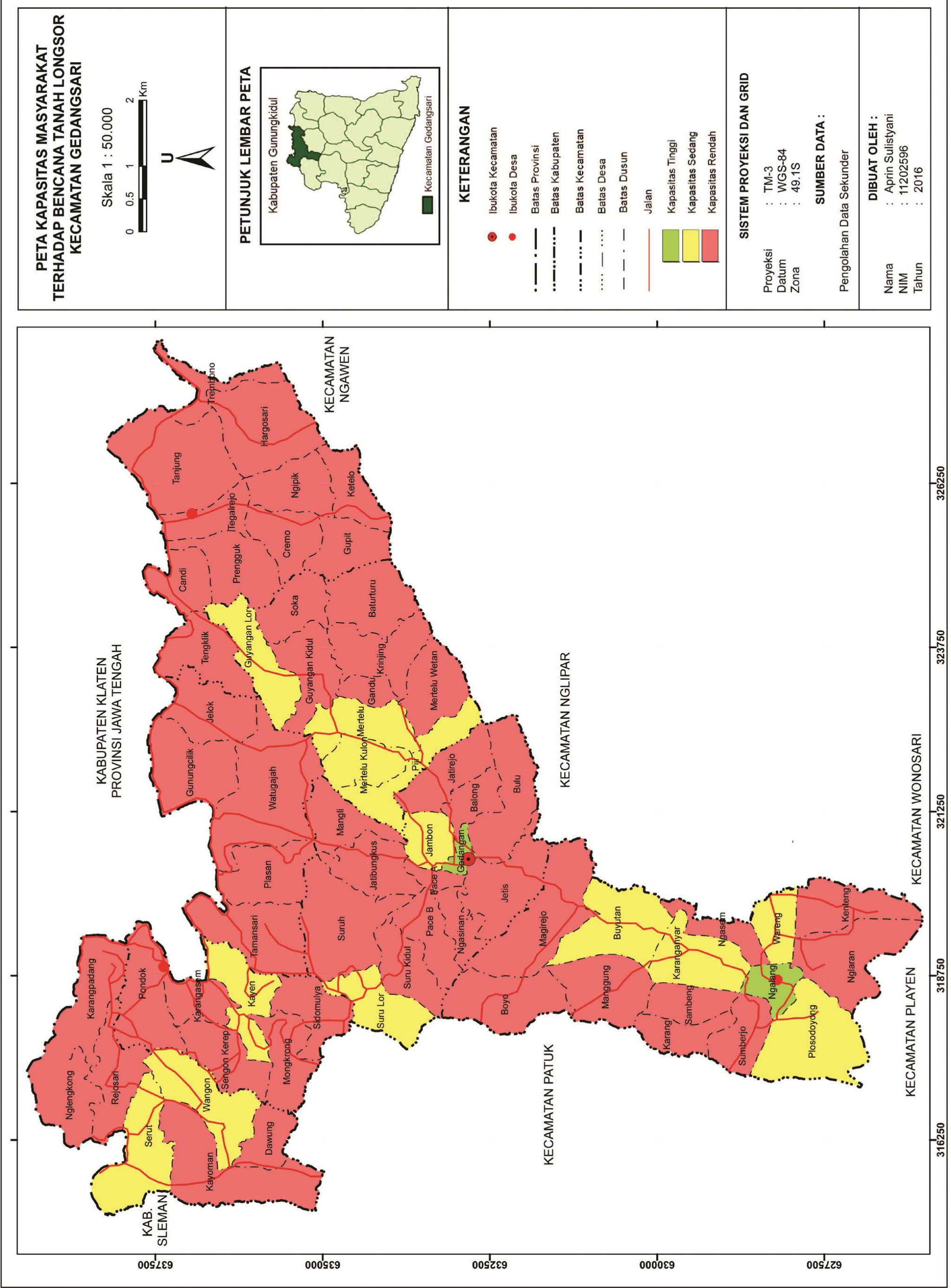

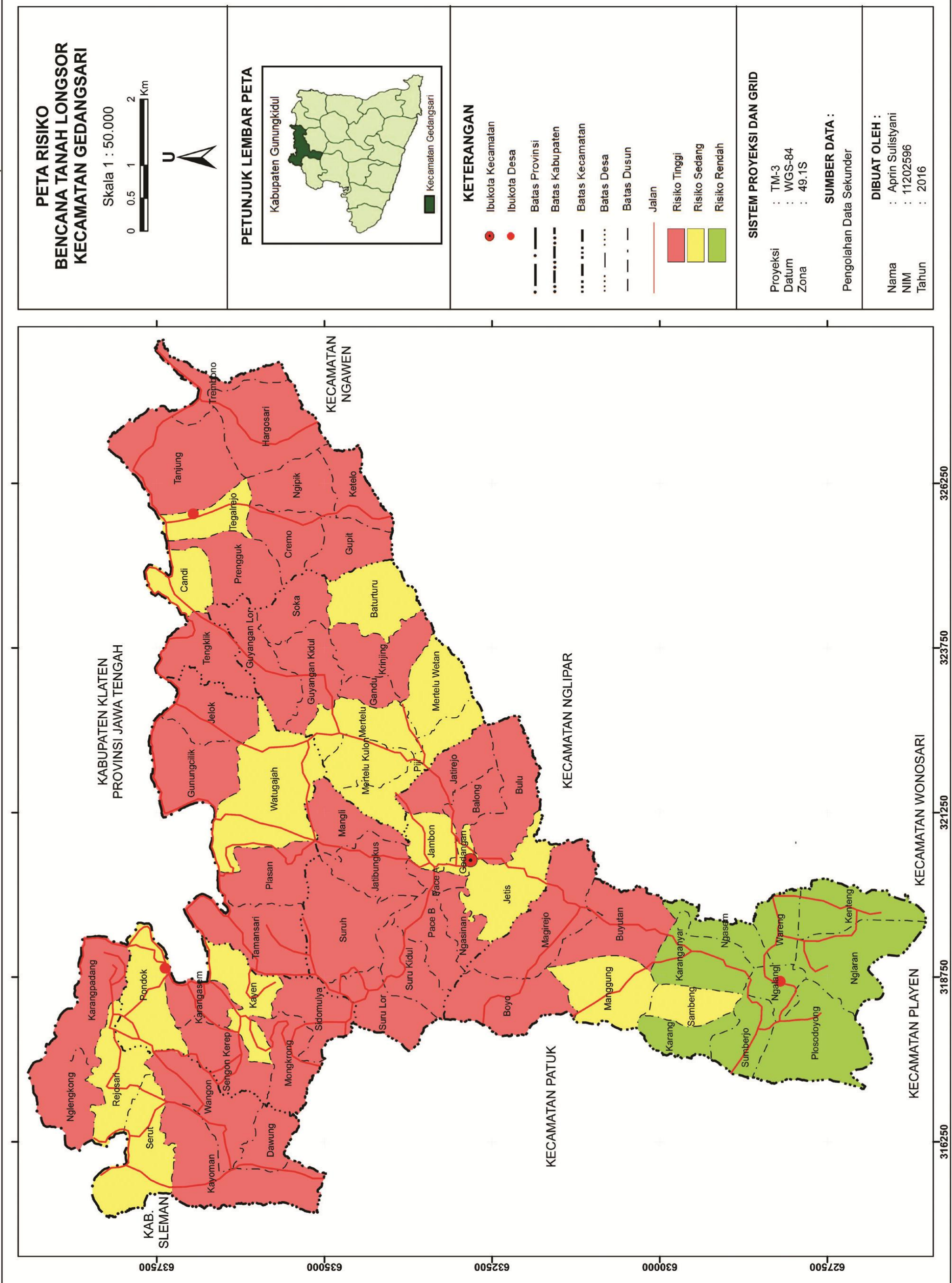

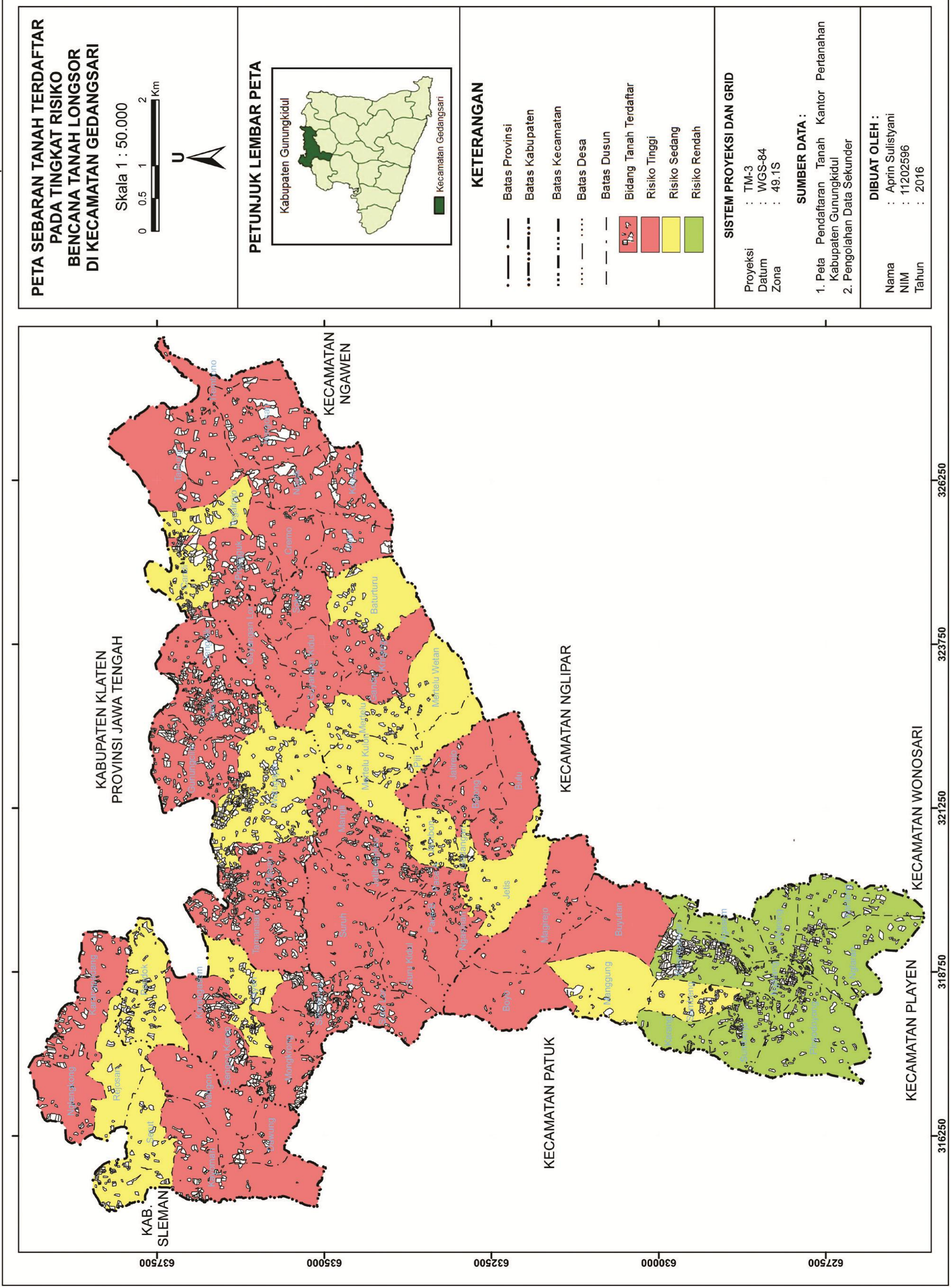

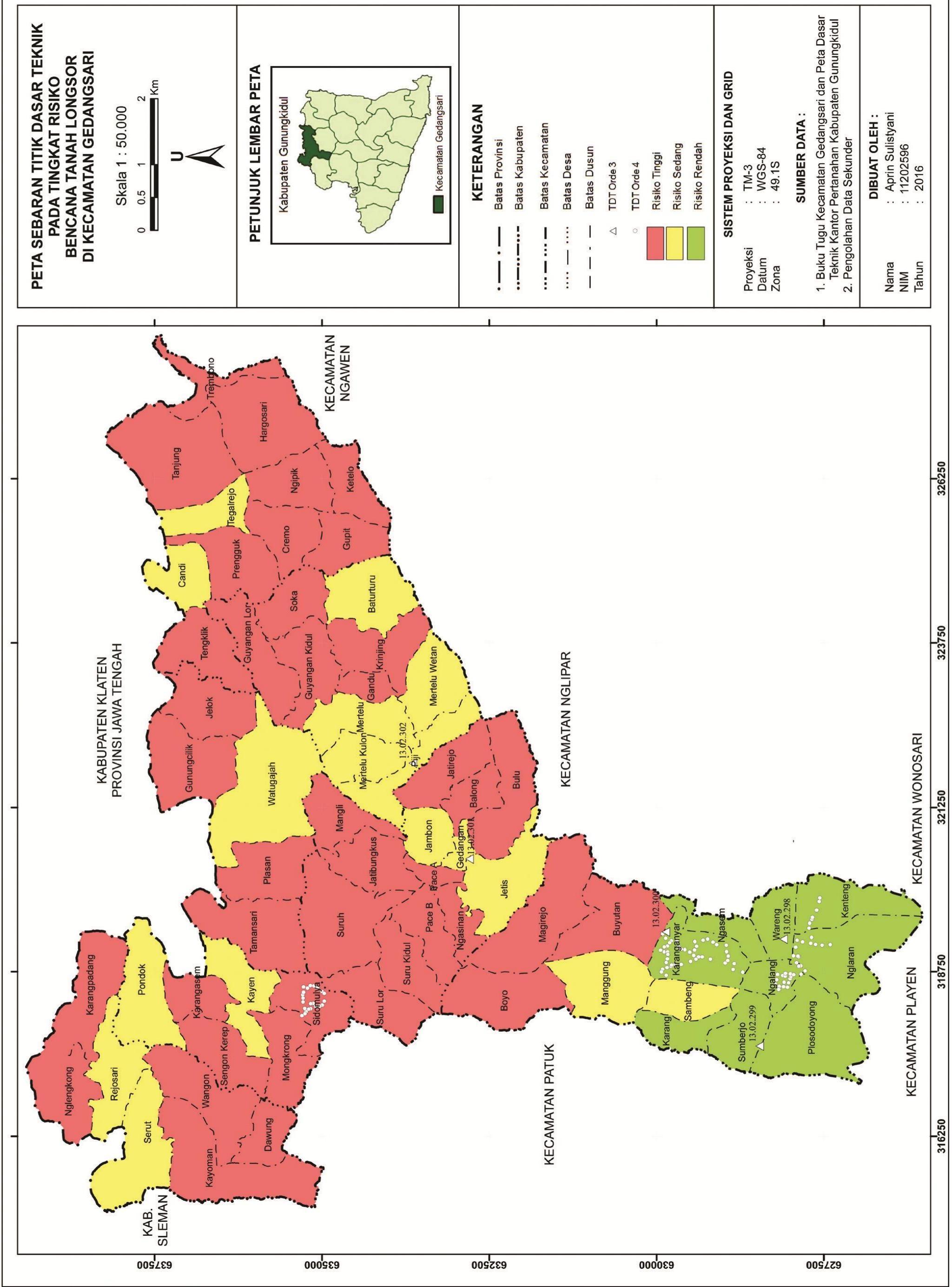